\title{
Hyperbenthic food-web structure in an Arctic fjord
}

\author{
Maeve McGovern ${ }^{1,2,3,4,6, *}$, Jørgen Berge ${ }^{2,3}$, Beata Szymczycha ${ }^{5}$, \\ Jan Marcin Węsławski ${ }^{5}$, Paul E. Renaud ${ }^{1,2}$ \\ ${ }^{1}$ Akvaplan-niva, Fram Centre for Climate and the Environment, 9296 Tromsø, Norway \\ ${ }^{2}$ University of Tromsø, 9027 Tromsø, Norway \\ ${ }^{3}$ University Centre in Svalbard, 9171 Longyearbyen, Norway \\ ${ }^{4}$ Nord University, Faculty of Biosciences and Aquaculture, Postbox 1490, 8049 Bodø, Norway \\ ${ }^{5}$ Institute of Oceanology PAS, ul. Powstancow Warszawy 55, 81-712 Sopot, Poland \\ ${ }^{6}$ Present address: Norwegian Institute for Water Research, Gaustadalleen 21, 0349 Oslo, Norway
}

\begin{abstract}
Current knowledge of the Arctic marine ecosystem is based primarily on studies performed during the polar day on the pelagic and benthic realms. Both the polar night and the hyperbenthic layer remain as substantial knowledge gaps in our understanding of the marine system at high latitudes. This study investigated the hyperbenthic food web in Kongsfjord, a highlatitude, ice-free fjord, in September 2014 and January 2015. The hyperbenthic food web was analyzed using a multi-biomarker approach including stable isotopes of carbon and nitrogen as well as fatty acid profiles of a variety of hyperbenthic taxa. While results suggested no difference in biomarker composition between September and January, they indicated a division in the sampled hyperbenthic species assemblage between pelagic and benthic feeders in both sampling periods. The presence of these 2 food-web pathways may have implications for maintaining higher trophic levels through the polar night, thereby enhancing stability in the Kongsfjord system.
\end{abstract}

KEY WORDS: Hyperbenthos - Suprabenthos · Benthic-boundary layer zooplankton · Kongsfjord · Stable isotopes $\cdot$ Fatty acids $\cdot$ Benthic-pelagic coupling

\section{INTRODUCTION}

\section{Arctic food web}

Knowledge of food-web structure, including the length, connectivity, and primary sources of trophic pathways, is important for our understanding of ecosystem function. Food webs can help distinguish pathways of biogeochemical and contaminant cycling, as well as elucidate the relationships between biodiversity and ecosystem functioning. Knowledge of energy flow can also provide insight into how the community may be impacted by future biotic and abiotic change such as species introductions, altered patterns in productivity, warming temperatures, and other environmental and anthropogenic changes (Renaud et al. 2011). In the marine system, direct observation of

${ }^{*}$ Corresponding author: maeve.mcgovern@niva.no feeding is usually impractical, so ecologists must depend on indirect methods for examining diet. Basic approaches, such as dissecting gut contents or fecal pellets, can be useful, but these can also be misleading, as they tend to underestimate the importance of soft and highly digestible food items and overestimate that of recently consumed items (Kelly \& Scheibling 2012). Biochemical tracer methods such as stable isotope analysis and fatty acid biomarker analysis can provide a time-integrated measure of food source and trophic position. Fatty acids are useful biomarkers for trophic studies, as they tend to remain intact within tissues and can accumulate over time, representing dietary intake over longer time scales (Dalsgaard et al. 2003). Fatty acids are synthesized in characteristic ways by different groups of organisms, and their tendency to remain intact

() The authors 2018. Open Access under Creative Commons by Attribution Licence. Use, distribution and reproduction are unrestricted. Authors and original publication must be credited. 
through the food chain allows scientists to identify prey items from predator tissues (Table 1).

In the Arctic, food-web studies using stable isotopes and fatty acids have demonstrated the importance of alternative carbon sources and pelagic-benthic coupling, and have identified regional differences in carbon sources for benthic communities (Renaud et al. 2011, 2015, Kędra et al. 2012). Due to the episodic nature of phytoplankton production at high latitudes, the spring bloom often provides more organic carbon than herbivorous zooplankton can consume, and many phytoplankton cells sink to the benthos where they maintain a flourishing benthic community (Morata \& Renaud 2008). The significant transfer of organic matter and its efficient assimilation by the benthic community (Grebmeier \& Barry 1991, Ambrose \& Renaud 1995) leads to tight pelagic-benthic coupling in Arctic ecosystems. Pelagic-benthic coupling has several implications for carbon cycling. Upon reaching the benthos, organic matter may be stored as benthic biomass, used for growth and reproduction, respired and remineralized into $\mathrm{CO}_{2}$ and dissolved organic carbon, or buried and sequestered in the sediments.

Climate warming has accelerated over the past $30 \mathrm{yr}$, with the Arctic recording the most extreme changes (IPCC 2013). While climate warming has no effect on the seasonal cycle in sunlight, it has greatly impacted sea-ice extent and thickness. Models predict an $80 \%$ loss of sea ice in summer and a $20 \%$ loss of sea ice in winter by 2100 (Johannessen et al. 2004). With these dramatic changes, ice-dominated coastal systems are likely to see substantial changes in carbon inputs as well as in pelagic-benthic coupling. We may conclude, therefore, that food-web structure in Arctic coastal areas will change as global temperatures increase (Kortsch et al. 2015). Changes in food-web structure could have implications for the biological pump and the sequestration of carbon from the atmosphere (Nishino et al. 2011). It is of interest, therefore, to investigate the seasonality of food-web structure and to identify potential sources of stability in order to better understand how these high latitude systems may respond to warming temperatures.

\section{Hyperbenthos}

We use the term 'hyperbenthos' to refer to the group of small marine organisms that dominate the layer of water just above the seafloor. Mainly crustaceans of pelagic and benthic origin, these organisms may be either part-time or permanent residents of this near-bottom water layer, which can range from just a few $\mathrm{cm}$ off the seafloor to several 10s of $\mathrm{m}$ into the water column (Koulouri et al. 2013). Unfortunately, the hyperbenthos has had a variety of other names, including suprabenthos, nektobenthos, hypoplankton, benthic boundary layer (BBL) zooplankton, semiplankton, demersal zooplankton, and benthopelagic plankton, which has resulted in a lack of coherence within the literature (Dauvin \& Vallet 2006).

Our knowledge of the hyperbenthos is relatively limited, due in part to the greater interest and focus on the pelagic and benthic regions, which are easier to sample. This is unfortunate because what we do know about the hyperbenthos suggests that they play a key role in several ecosystem functions (Graf \& Rosenberg 1997). Many hyperbenthic species are known to migrate daily out of the hyperbenthos into the pelagic (Rudstam et al. 1986). These species may contribute to the export of carbon when they feed on resources from the pelagic and respire and produce fecal pellets at depth (Darnis \& Fortier 2012). This migration also strengthens an essential link in the

Table 1. Summary of fatty acids (FAs) used as dietary tracers in this paper. PUFA: polyunsaturated fatty acids; SFA: saturated fatty acids

\begin{tabular}{|c|c|c|}
\hline & Dietary FA tracers & References \\
\hline Dinoflagellates & C18 PUFA + 22:6 $\omega-3$ & Falk-Petersen et al. (1998), Kelly \& Scheibling (2012) \\
\hline Diatoms & C16 PUFA + 16:1 $\omega-7+20: 5 \omega-3$ & $\begin{array}{l}\text { Nelson et al. (2001), Reuss \& Poulsen (2002), } \\
\text { Dalsgaard et al. (2003) }\end{array}$ \\
\hline Macroalgae & 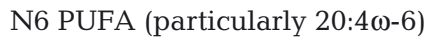 & Dalsgaard et al. (2003) \\
\hline Bacteria & $\mathrm{C} 15+\mathrm{C} 17$ & $\begin{array}{l}\text { Sargent et al. (1987), Dalsgaard et al. (2003), } \\
\text { Volkman et al. (1980) }\end{array}$ \\
\hline Detritus & $\begin{array}{l}\text { SFA (particularly 18:0), } \\
18: 0+18: 1 \omega-9\end{array}$ & Søreide et al. (2008), Mayzaud et al. (2013b) \\
\hline Carnivorous feeding & $18: 1 \omega-9 / 18: 1 \omega-7$ & Sargent \& Falk-Petersen (1981), Graeve et al. (1997) \\
\hline Copepods & $20: 1+22: 1$ MUFA & Sargent \& Falk-Petersen (1988) \\
\hline Terrestrial vegetation & $22: 0+24: 0$ & Budge \& Parrish (1998) \\
\hline
\end{tabular}


food chain between pelagic producers and benthic consumers (Mees \& Jones 1997). Hyperbenthic taxa are also an essential food source for demersal fish and adult shrimp species, as documented in shallow and coastal areas (Hostens \& Mees 1999). A study on the feeding habits of cod in 1982 in Balsfjord in northern Norway found that the 11 most important species were all inhabitants of the hyperbenthic zone (Klemetsen 1982).

Despite their role in carbon and nutrient cycling, and their importance as a food source for key commercial fish species, few studies have focused on the chemical composition or feeding ecology of hyperbenthic species (Mees \& Jones 1997), particularly in the Arctic (but see Legeżyńska 2008, Legeżyńska et al. 2012, 2014).

This study aimed to describe the food web structure of an assemblage of hyperbenthic species in Kongsfjord, a high-latitude and ice-free fjord, in September and January. The hyperbenthic food web was analyzed using a multi-biomarker approach including fatty acid trophic markers as well as carbon and nitrogen isotopic signatures of a variety of hyperbenthic taxa. A combination of pelagic production, macroalgae, detritus, and terrestrial inputs were expected to make up much of the carbon pool. With this study, we hoped to shed light on the role of hyperbenthos in the functioning of high Arctic ecosystems.

\section{MATERIALS AND METHODS}

\section{Sampling}

Sample collection took place in Kongsfjord (Fig. 1), onboard the R/V 'Helmer Hanssen'. The first batch of samples was collected from 23 to 26 September 2014; the second batch was collected from 12 to 15 January 2015. Samples were collected from 23 locations within Kongsfjord (Svalbard, Norway) at $79^{\circ}$ N (Fig. 1) using 4 different sampling gears (Table 2). An epibenthic sled (EBS) was used to collect hyperbenthic organisms just above the seafloor at depths ranging from 53 to $338 \mathrm{~m}$. The EBS had 2 stacked nets, each $100 \mathrm{~cm}$ wide and $33 \mathrm{~cm}$ high, with a $500 \mu \mathrm{m}$ mesh size. The EBS was slowly lowered to the seafloor, where it was towed for 10 min at speeds ranging from 0.1 to 3.1 knots, before being hauled to the surface. The nets were rinsed with a hose, each sample was then sieved to remove excess mud, and organisms were sorted by species. Fish and large invertebrates were collected using a bottom trawl (BT) at 102 and $285 \mathrm{~m}$. All organisms (Table 3) were packed in aluminum foil and frozen at $-20^{\circ} \mathrm{C}$ for stable isotope analysis and at $-80^{\circ} \mathrm{C}$ for fatty acid marker analysis. Sample sizes ranged from 1 to 5 replicates species ${ }^{-1}$. Muscle tissue was collected from fish and large crustaceans, while the entire body was used for smaller

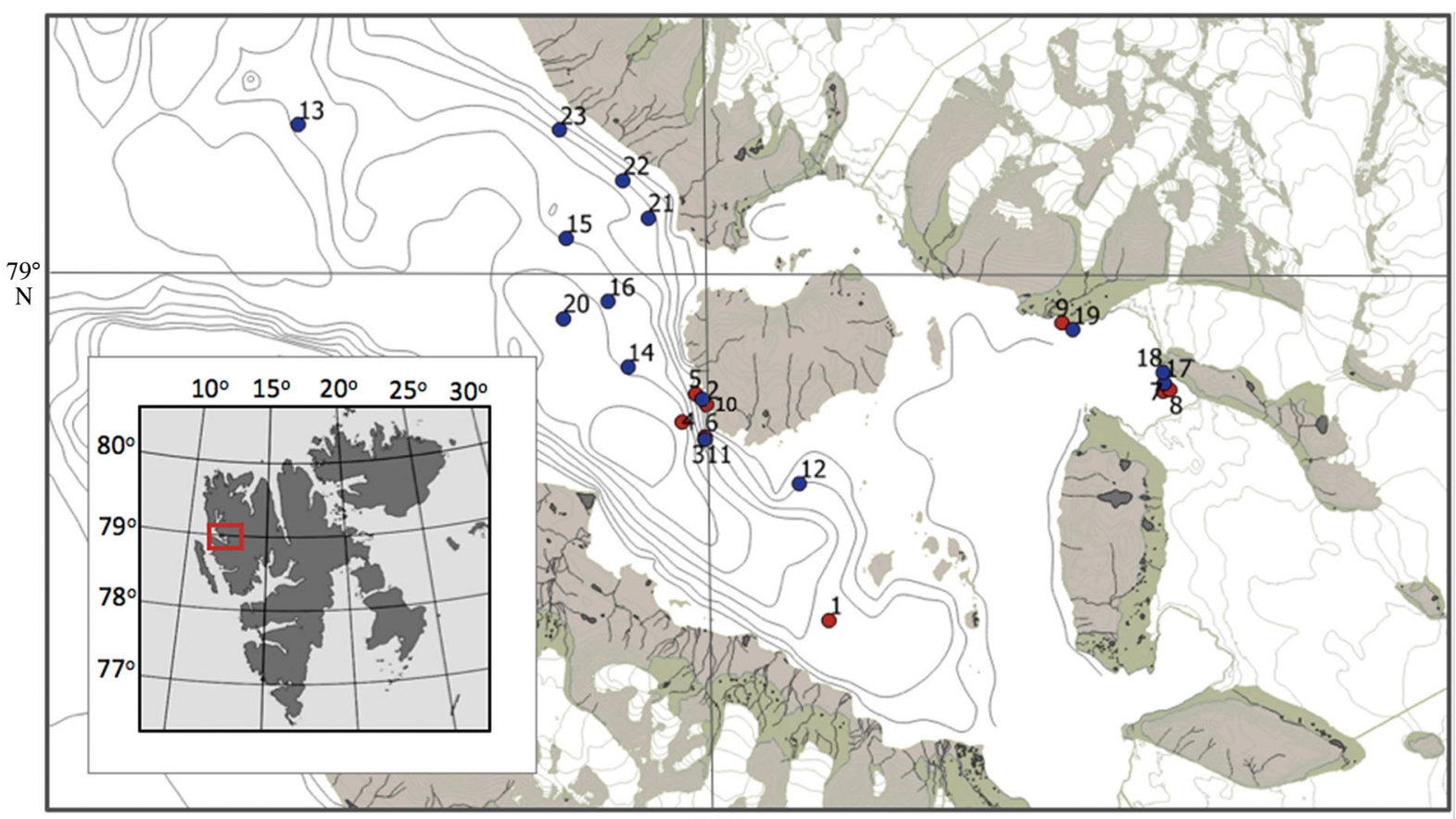

$12^{\circ} \mathrm{E}$

Fig. 1. Study area in Kongsfjord. Numbers indicate sampling stations, color indicates year: red $=$ September 2014 , blue $=$ January 2015 
Table 2. Sampling sites and collection information. ID no.: station number referred to in Fig. 1. BT: bottom trawl; CTD: Niskin bottles on CTD rosette collected at depth; EBS: epi-benthic sled

\begin{tabular}{|c|c|c|c|c|c|}
\hline ID no. & $\begin{array}{c}\text { Date } \\
\text { (dd/mm/yy) }\end{array}$ & Gear & Latitude & Longitude & $\begin{array}{l}\text { Depth } \\
\text { (m) }\end{array}$ \\
\hline 1 & $23 / 09 / 14$ & BT & $78^{\circ} 55.09^{\prime} \mathrm{N}$ & $12^{\circ} 08.98^{\prime} \mathrm{E}$ & 102 \\
\hline 2 & $24 / 09 / 14$ & EBS & $78^{\circ} 57.64^{\prime} \mathrm{N}$ & $11^{\circ} 59.56^{\prime} \mathrm{E}$ & 88 \\
\hline 3 & $24 / 09 / 14$ & EBS & $78^{\circ} 57.35^{\prime} \mathrm{N}$ & $11^{\circ} 59.60^{\prime} \mathrm{E}$ & 203 \\
\hline 4 & $24 / 09 / 14$ & CTD & $78^{\circ} 57.49^{\prime} \mathrm{N}$ & $11^{\circ} 57.75^{\prime} \mathrm{E}$ & 336 \\
\hline 5 & 26/09/14 & EBS & $78^{\circ} 57.73^{\prime} \mathrm{N}$ & $11^{\circ} 59.05^{\prime} \mathrm{E}$ & 109 \\
\hline 6 & $26 / 09 / 14$ & EBS & $78^{\circ} 57.37^{\prime} \mathrm{N}$ & $11^{\circ} 59.58^{\prime} \mathrm{E}$ & 201 \\
\hline 7 & $25 / 09 / 14$ & CTD & $78^{\circ} 58.33^{\prime} \mathrm{N}$ & $12^{\circ} 33.01^{\prime} \mathrm{E}$ & 137 \\
\hline 8 & $25 / 09 / 14$ & EBS & $78^{\circ} 58.34^{\prime} \mathrm{N}$ & $12^{\circ} 32.89^{\prime} \mathrm{E}$ & 135 \\
\hline 9 & $25 / 09 / 14$ & EBS & $78^{\circ} 58.87^{\prime} \mathrm{N}$ & $12^{\circ} 25.29^{\prime} \mathrm{E}$ & 53 \\
\hline 10 & $12 / 01 / 15$ & EBS & $78^{\circ} 57.69^{\prime} \mathrm{N}$ & $11^{\circ} 59.35^{\prime} \mathrm{E}$ & 101 \\
\hline 11 & $12 / 01 / 15$ & EBS & $78^{\circ} 56.95^{\prime} \mathrm{N}$ & $12^{\circ} 00.01^{\prime} \mathrm{E}$ & 207 \\
\hline 12 & $12 / 01 / 15$ & CTD & $78^{\circ} 56.62^{\prime} \mathrm{N}$ & $12^{\circ} 06.60^{\prime} \mathrm{E}$ & 232 \\
\hline 13 & $12 / 01 / 15$ & $\mathrm{BT}$ & $79^{\circ} 01.39^{\prime} \mathrm{N}$ & $11^{\circ} 28.68^{\prime} \mathrm{E}$ & 285 \\
\hline 14 & $13 / 01 / 15$ & EBS & $78^{\circ} 57.92^{\prime} \mathrm{N}$ & $11^{\circ} 54.06^{\prime} \mathrm{E}$ & 338 \\
\hline 15 & $13 / 01 / 15$ & EBS & $79^{\circ} 00.17^{\prime} \mathrm{N}$ & $11^{\circ} 49.06^{\prime} \mathrm{E}$ & 205 \\
\hline 16 & $13 / 01 / 15$ & CTD & $78^{\circ} 59.26^{\prime} \mathrm{N}$ & $11^{\circ} 51.87^{\prime} \mathrm{E}$ & 258 \\
\hline 17 & $14 / 01 / 15$ & CTD & $78^{\circ} 58.40^{\prime} \mathrm{N}$ & $12^{\circ} 32.68^{\prime} \mathrm{E}$ & 136 \\
\hline 18 & $14 / 01 / 15$ & EBS & $78^{\circ} 58.49^{\prime} \mathrm{N}$ & $12^{\circ} 32.56^{\prime} \mathrm{E}$ & 139 \\
\hline 20 & $15 / 01 / 15$ & EBS & $78^{\circ} 58.70^{\prime} \mathrm{N}$ & $11^{\circ} 49.13^{\prime} \mathrm{E}$ & 295 \\
\hline 21 & $15 / 01 / 15$ & EBS & $79^{\circ} 00.38^{\prime} \mathrm{N}$ & $11^{\circ} 55.00^{\prime} \mathrm{E}$ & 122 \\
\hline 22 & $15 / 01 / 15$ & EBS & $79^{\circ} 01.08^{\prime} \mathrm{N}$ & $11^{\circ} 53.02^{\prime} \mathrm{E}$ & 154 \\
\hline 23 & $15 / 01 / 15$ & CTD & $79^{\circ} 01.47^{\prime} \mathrm{N}$ & $11^{\circ} 48.15^{\prime} \mathrm{E}$ & 169 \\
\hline
\end{tabular}

Table 3. Species collected from Kongsfjord with the type of sample taken during each sampling period. A: Amphipoda; M: Mysida; E: Euphausiida; D: Decapoda; Ch: Chaetognatha; F: fish; C: Copepoda; MA: macroalgae; POM: bottom water particulate organic matter. SI: stable isotopes; FA: fatty acid profiles. Label: species abbreviation used in figures

\begin{tabular}{|c|c|c|c|c|}
\hline $\begin{array}{l}\text { Taxonomic } \\
\text { group }\end{array}$ & Species & $\begin{array}{l}\text { Sep } \\
2014\end{array}$ & $\begin{array}{c}\text { Jan } \\
2015\end{array}$ & Label \\
\hline A & Acanthostepheia malmgreni & SI & SI & Am \\
\hline A & Andaniexis lupus & SI, FA & SI & $\mathrm{Al}$ \\
\hline A & Arrhis phyllonyx & SI, FA & SI, FA & Ap \\
\hline A & Halirages fulvocinctus & SI, FA & SI, FA & Hf \\
\hline A & Syrrhoe crenulata & SI & SI & $\mathrm{Sc}$ \\
\hline M & Erythrops erythropthalma & SI & SI & $\mathrm{Ee}$ \\
\hline E & Thysanoessa inermis & SI & SI & $\mathrm{Ti}$ \\
\hline $\mathrm{D}$ & Pandalus borealis (large) & SI, FA & SI, FA & $\mathrm{Pbl}$ \\
\hline $\mathrm{D}$ & Pandalus borealis (small) & SI, FA & SI, FA & $\mathrm{Pbs}$ \\
\hline $\mathrm{D}$ & Sabinea septemcarinata & SI, FA & SI, FA & Ss \\
\hline $\mathrm{D}$ & Lebbeus polaris & & SI & $\mathrm{Lp}$ \\
\hline $\mathrm{Ch}$ & Parasagitta elegans & SI, FA & SI, FA & $\mathrm{Pe}$ \\
\hline $\mathrm{F}$ & Hippoglossoides platessoides & SI, FA & SI, FA & $\mathrm{Hp}$ \\
\hline $\mathrm{F}$ & Gadus morhua & SI, FA & & $\mathrm{Gm}$ \\
\hline $\mathrm{F}$ & Melanogrammus aeglefinus & SI, FA & SI, FA & $\mathrm{Ma}$ \\
\hline $\mathrm{F}$ & Boreogadus saida & & SI & $\mathrm{Bs}$ \\
\hline $\mathrm{F}$ & Leptoclinus maculatus & & SI & Lm \\
\hline $\mathrm{C}$ & Calanus spp. & FA & & Cs \\
\hline MA & Laminaria digitata & FA & & $\mathrm{Ld}$ \\
\hline MA & Desmarestia aculeata & FA & & $\mathrm{Da}$ \\
\hline MA & Rhodomela confervoides & FA & & $\mathrm{Rc}$ \\
\hline POM & Bottom water POM & SI, FA & SI, FA & POM \\
\hline
\end{tabular}

organisms. Samples of Pandalus borealis were sorted into 2 size classes: individuals with a carapace length greater than $2.5 \mathrm{~cm}$ and those with a carapace length smaller than or equal to $2.5 \mathrm{~cm}$ (Hansen $\&$ Aschan 2000). The number of individuals in each sample ranged from 1 for large decapods and fish samples, to 15 or 30 for small amphipods, chaetognaths, and copepods. Upon return to the lab, samples for stable isotope analysis were dried to constant mass at $60^{\circ} \mathrm{C}$. Particulate organic matter (POM) of bottom water was collected using Niskin bottles on a CTD rosette 10 to $15 \mathrm{~m}$ above the bottom at the location of each EBS. The water was filtered (2 to 31 filter $^{-1}$ ) onto pre-combusted (at $450^{\circ} \mathrm{C}$ for $12 \mathrm{~h}$ ) $0.7 \mu \mathrm{m}$ GF/F glass microfiber filters. Three replicates were taken for fatty acid and 3 for stable isotope analysis, and filters were frozen at the respective temperatures mentioned above.

\section{Stable isotope analysis}

Bulk stable isotope analysis was performed at the Institute of Oceanology PAS (IOPAS) in Sopot, Poland, according to methods suggested by Søreide et al. (2006). Powdered samples were dried in an oven at $60^{\circ} \mathrm{C}$. A subsample was then packed in tin capsules, weighed to the nearest $\mu \mathrm{g}$ and analyzed for $\delta^{15} \mathrm{~N}$. A second subsample was taken for lipid and calcium carbonate removal. Lipids were extracted from the samples in 2:1 (by volume) chloroform-methanol solution (2:1 CM) overnight at room temperature. After extraction, samples were quickly rinsed in new 2:1 CM and then air-dried under a fume hood at room temperature. Following lipid removal, samples underwent acidification for removal of calcium carbonate. Dried samples were wetted in $2 \mathrm{M} \mathrm{HCl}$ and then dried at $60^{\circ} \mathrm{C}$. This process was repeated 4 times. These samples were then dried, packed in capsules, weighed, and analyzed for $\delta^{13} \mathrm{C}$ measurements. The analyses were performed in an Elemental Analyzer Flash EA 1112 Series combined with a Delta V 
Advantage Isotopic Ratio Mass Spectrometer (Thermo Electron). Isotopic ratios of $\delta^{13} \mathrm{C}$ and $\delta^{15} \mathrm{~N}$ were calculated using pure laboratory reference gases $\mathrm{CO}_{2}$ and $\mathrm{N}_{2}$ calibrated against IAEA standards: $\mathrm{CO}-8$ and USGS40 for $\delta^{13} C_{;}$and N-1 and USGS4 0 for $\delta^{15} \mathrm{~N}$. Internal standards were Pee Dee Belemnite and Atmospheric $\mathrm{N}_{2} . \delta^{13} \mathrm{C}$ were $\delta^{15} \mathrm{~N}$ are calculated as follows:

$$
\left.\delta \mathrm{X}=\left[R_{\text {sample }} / R_{\text {standard }}\right)-1\right] \times 1000
$$

where $x=$ carbon or nitrogen, $R=$ the appropriate ratio $\left({ }^{13} \mathrm{C}:{ }^{12} \mathrm{C}\right.$ or $\left.{ }^{15} \mathrm{~N}:{ }^{14} \mathrm{~N}\right)$, of the sample and of the standards.

\section{Fatty acid analysis}

Fatty acid (FA) profiles were run at Akvaplanniva in Tromsø, Norway. Total lipids were extracted according to Folch et al. (1957). A known amount of the FA 21:0 was added to the samples of extracted total lipid as an internal standard. An acid-catalyzed transesterification was carried out with $1 \%$ sulphuric acid in methanol. The total lipid extract of each sample was cleaned on a silica column (Christie 1982). FAs were analyzed with an Agilent $6890 \mathrm{~N}$ gas chromatograph equipped with a fused silica, wall-coated capillary column $(50 \mathrm{~m}$ $\times 0.25 \mathrm{~mm}$ i.d.; Varian Select FAME), and an Agilent 7683 injector and flame ionization detection. Hydrogen was used as the carrier gas. Samples were injected at $280^{\circ} \mathrm{C}_{i}$ the thermal gradient was raised from 60 to $150^{\circ} \mathrm{C}$ at $30^{\circ} \mathrm{C} \mathrm{min}^{-1}$, and then to a final temperature of $230^{\circ} \mathrm{C}$ at $1.5^{\circ} \mathrm{C} \mathrm{min}{ }^{-1}$, and kept there for 2 min. Individual methyl esters of FAs were identified by comparison with 3 known standards (GLC-96 and GLC-68D, quantitative standards from NU-CHEK Prep., and MARINOL qualitative standard obtained from the University of Stirling, ref. J. Henderson), and were quantified using HP ChemStation software (Hewlett-Packard) (Søreide et al. 2008).

\section{Statistical analysis}

Plots and statistics were done in R using the package 'vegan' (Oksanen et al. 2015). Correspondence analysis (CA) was used to visualize the FA profiles of the hyperbenthic taxa collected in each season. A 'contribution biplot' based on the CA ordination was used to visualize the most important FAs contributing to the output of the CA. This useful ordination technique makes it possible to both visualize the differ- ences among the taxa and seasons, and to determine the FAs primarily responsible for these differences. Only those FAs that had a higher than average contribution to each axis are pictured in the ordination (Greenacre \& Primicerio 2013). A permutation test (using the 'vegan' function 'anova(cca)', based on 999 free permutations) was used to test the significance of date, station, depth, and taxonomic group on the FA profiles. In addition, a simple linear regression was used to test the relationship between the FA $22: 6 \omega-3$ and $\delta^{15} \mathrm{~N}$.

\section{RESULTS}

\section{Stable isotopes}

Stable isotope analysis was performed on 16 species as well as near-bottom water POM. Values of $\delta^{13} \mathrm{C}$ were similar between seasons. In September, values in amphipods ranged from $-23.2 \%$ for Syrrhoe crenulata to $-19.8 \%$ for Arrhis phyllonyx. In January, values ranged from $-24.4 \%$ for $S$. crenulata to $-19.4 \%$ for A. phyllonyx. Values in decapods ranged from $-21.7 \%$ in the small size fraction of Pandalus borealis to $-20.8 \%$ in the large size fraction of $P$. borealis in September and from $-21.5 \%$ in the small size fraction of $P$. borealis to $-19.3 \%$ in Sabinea septemcarinata in January. The $\delta^{13} \mathrm{C}$ values for POM ranged from a mean of $-22.9 \%$ in September to $-24.0 \%$ in January (Fig. 2, Tables A1 \& A2 in the Appendix).

In September, the mean value of $\delta^{15} \mathrm{~N}$ for POM samples taken from 2 locations within the fjord was $5.9 \%$ while in January the mean taken from 3 locations was much lower, at $1.9 \%$.

All of the amphipods had higher $\delta^{15} \mathrm{~N}$ values in January relative to September. The increase in values from September to January ranged from $1.5 \%$ for Halirages fulvocinctus to $0.3 \%$ for $A$. phyllonyx (Fig. 2). Results were more variable for decapods. Values of $\delta^{15} \mathrm{~N}$ for some species were only $0.3 \%$ higher in winter (large $P$. borealis) (Fig. 2). As for the fish, Gadus morhua and Melanogrammus aeglefinus had the highest $\delta^{15} \mathrm{~N}$ values at 13.0 and $13.1 \%$ in September, respectively. Hippoglossoides platessoides had the highest values of $\delta^{13} \mathrm{C}$ for fish with values of $-19.9 \%$ in September and $-21.0 \%$ in January. M. aeglefinus had similar values with $-20.6 \%$ in September and $-21.4 \%$ in January. Gadus morhua, collected in September, had $\delta^{13} \mathrm{C}$ values of $-21.4 \%$ (Fig. 2, Tables A1 \& A2). 


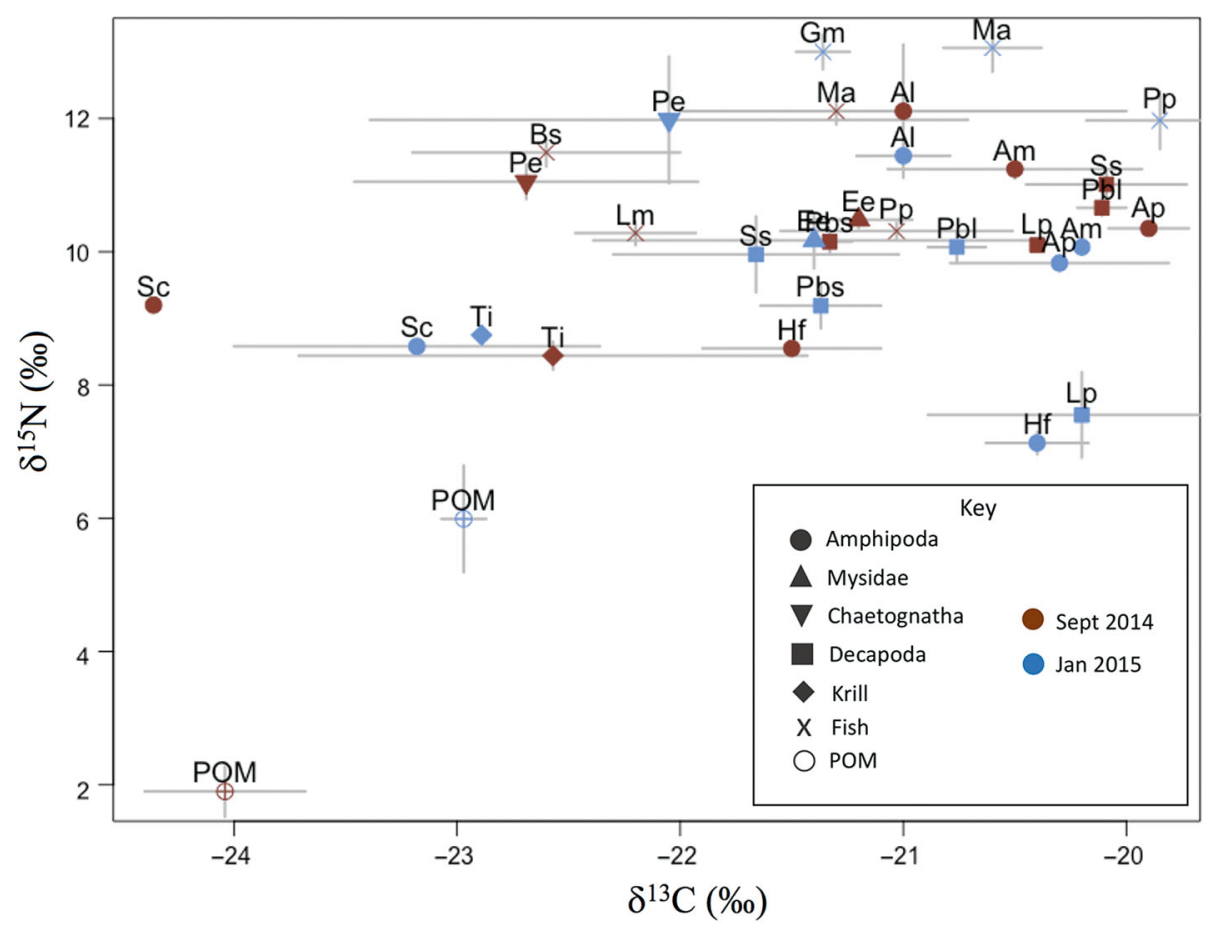

Fig. 2. $\delta^{13} \mathrm{C}$ versus $\delta^{15} \mathrm{~N}$ showing mean $( \pm \mathrm{SE})$ values for each taxon per season. Taxon abbreviations can be found under 'Label' in Table 3

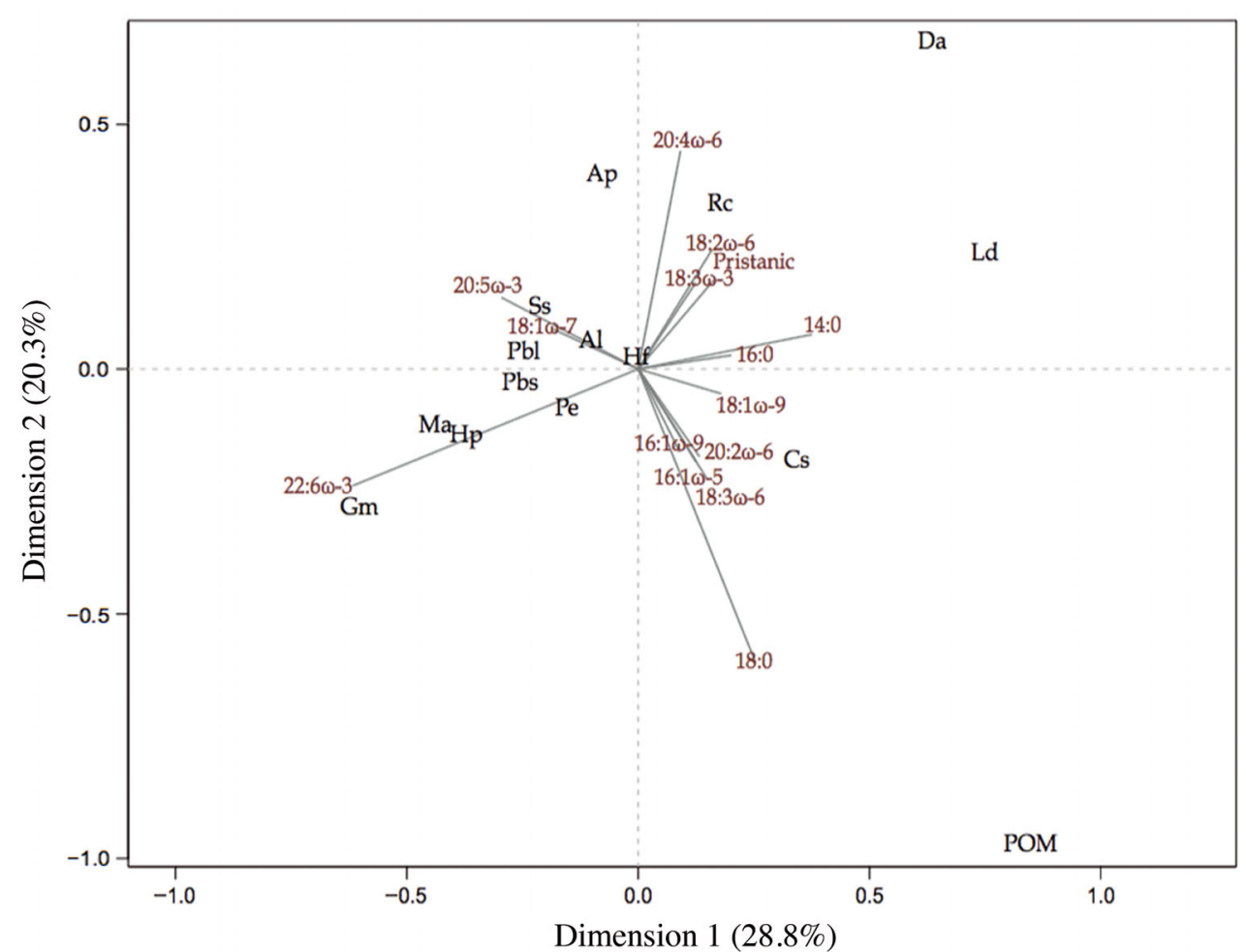

Fig. 3. Correspondence analysis (CA) contribution biplot of September (2014) data based on all 43 compositional fatty acids. Only those fatty acids with a greater than average contribution to the outcome of the CA ordination are shown, with vector lengths signifying the relative degree of contribution. Taxon identities can be found under 'Label' in Table 3. Axis labels indicate the total variance explained by each axis 


\section{Fatty acids}

Of the 43 FAs identified in our samples, 8 made up over half of the total FA concentration in all samples in both seasons. These included the short-chain saturated 16:0 and 18:0, the monoenes 16:1 $107,18: 1 \omega 9$, and 18:1 107 , and the long-chain polyunsaturated fatty

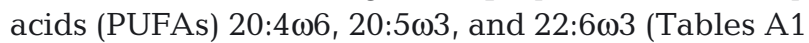
\& A2). The permutation test (ANOVA of CCA model) indicated that there were no significant trends in FA profiles with depth $\left(F_{1,11}=0.85, \mathrm{p}=0.517\right)$ or with season $\left(F_{1,11}=0.79, \mathrm{p}=0.690\right)$, but rather that taxonomic group best explained the variability in FA composition $\left(F_{4,11}=4.46, \mathrm{p}=0.001\right)$.

FA profiles of bottom water POM were similar between seasons. According to the CA contribution biplot (Figs. $3 \& 4$ ), the highest contributing fatty acids

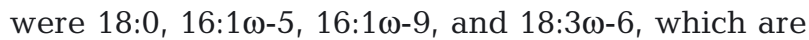
biomarkers for degraded detrital material and phytoplankton (Kelly \& Scheibling 2012). The highest

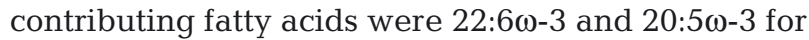
$M$. aeglefinus, $P$. borealis, and $H$. platessoides, and

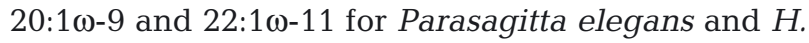

fulvocinctus. A. phyllonyx and $S$. septemcarinata were most strongly correlated with 20:4 $\omega-6$, a biomarker for a variety of sources including macroalgae and foraminifera, and the monounsaturated FA

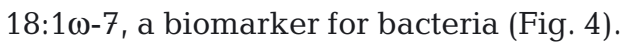

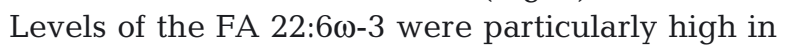
the fish samples, representing $43 \%$ of total FAs in $G$. morhua, but quite low in bottom water POM samples at $1 \%$ of total FA content in both seasons (Fig. 5a). The FA 20:5 $\omega-3$, known to be in high concentrations in diatoms (Nelson et al. 2001, Dalsgaard et al. 2003), was high in all faunal samples, constituting 10 to $25 \%$ of total FAs. Levels were low in bottom water POM samples in both seasons $(2 \%$ of total FAs in September and $1 \%$ in January). Levels were highest in S. septemcarinata, at 20 and $25 \%$ in September and January, respectively, as well as the large size class of $P$. borealis, at 21 and $22 \%$ in September and January, respectively (Fig. 5b).

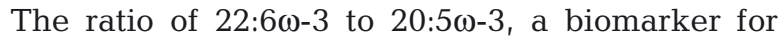
dinoflagellates, was highest in fish samples, at 3.2 for G. morhua in September, and 1.6 and 1.9 for $M$. aeglefinus in September and January, respectively

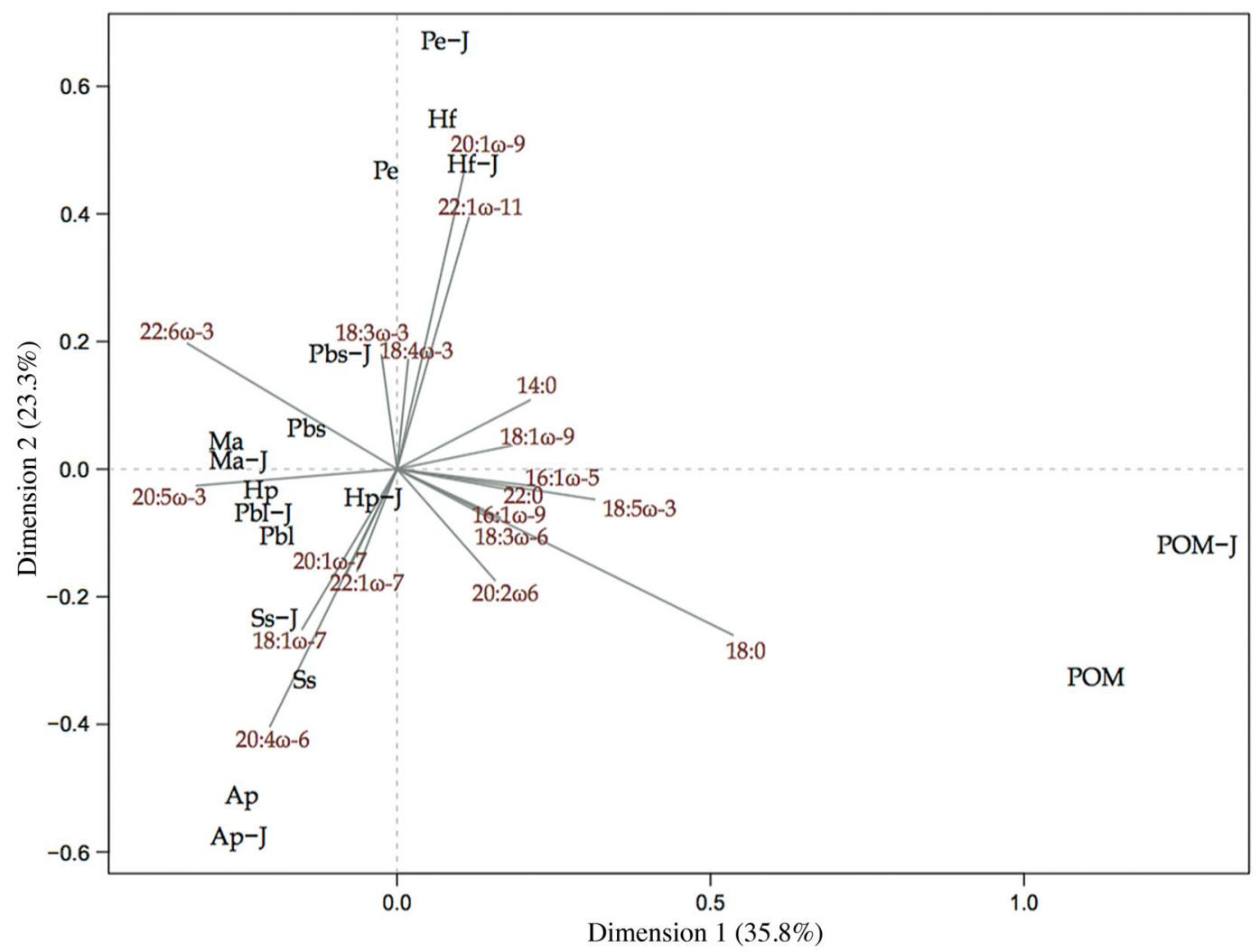

Fig. 4. Correspondence analysis (CA) contribution biplot based on 43 compositional fatty acids. Only species collected in both seasons (Sep 2014 and Jan 2015) are included. January samples are indicated with a 'J' following the taxon abbreviation, which can be found under 'Label' in Table 3. Fatty acids with a greater than average contribution to the outcome of the CA ordination are shown. Axis labels indicate the percent variance explained by each axis 

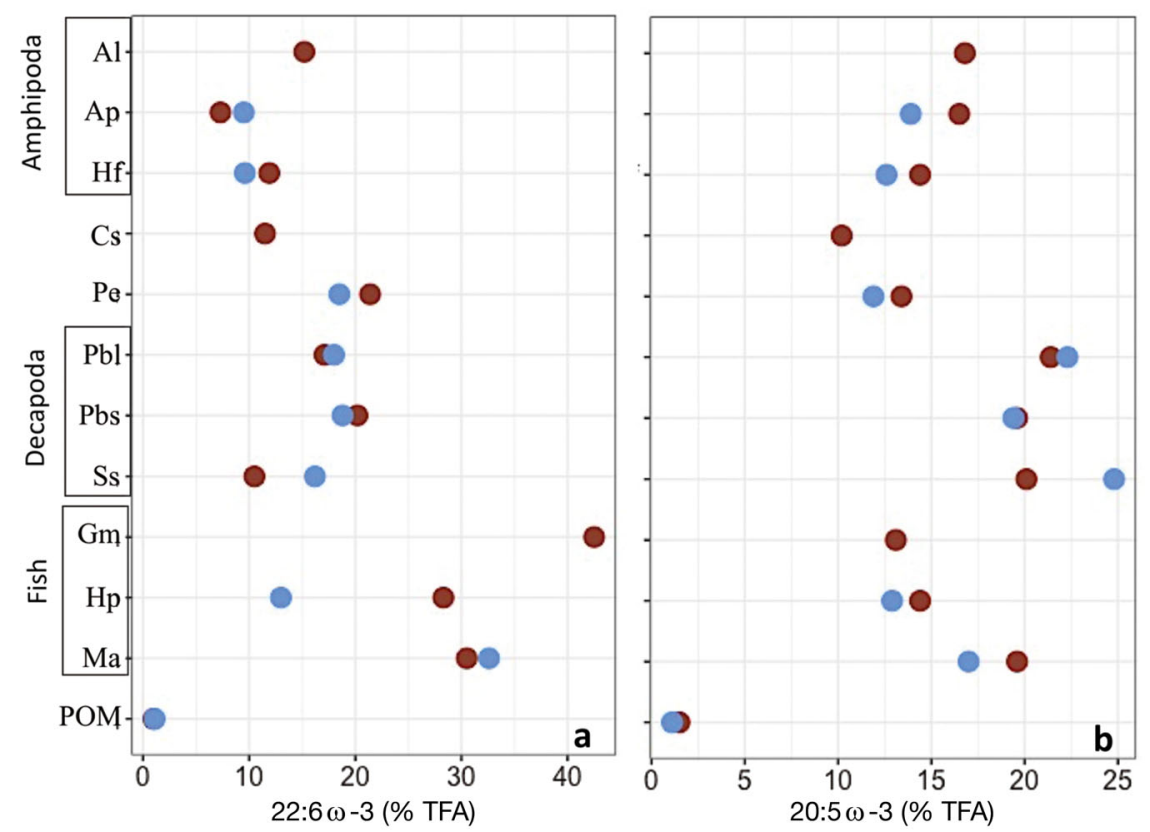

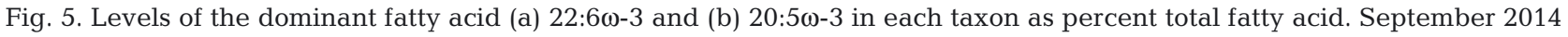
samples are in red; January 2015 samples are in blue. Taxon abbreviations on left axis can be found under 'Label' in Table 3
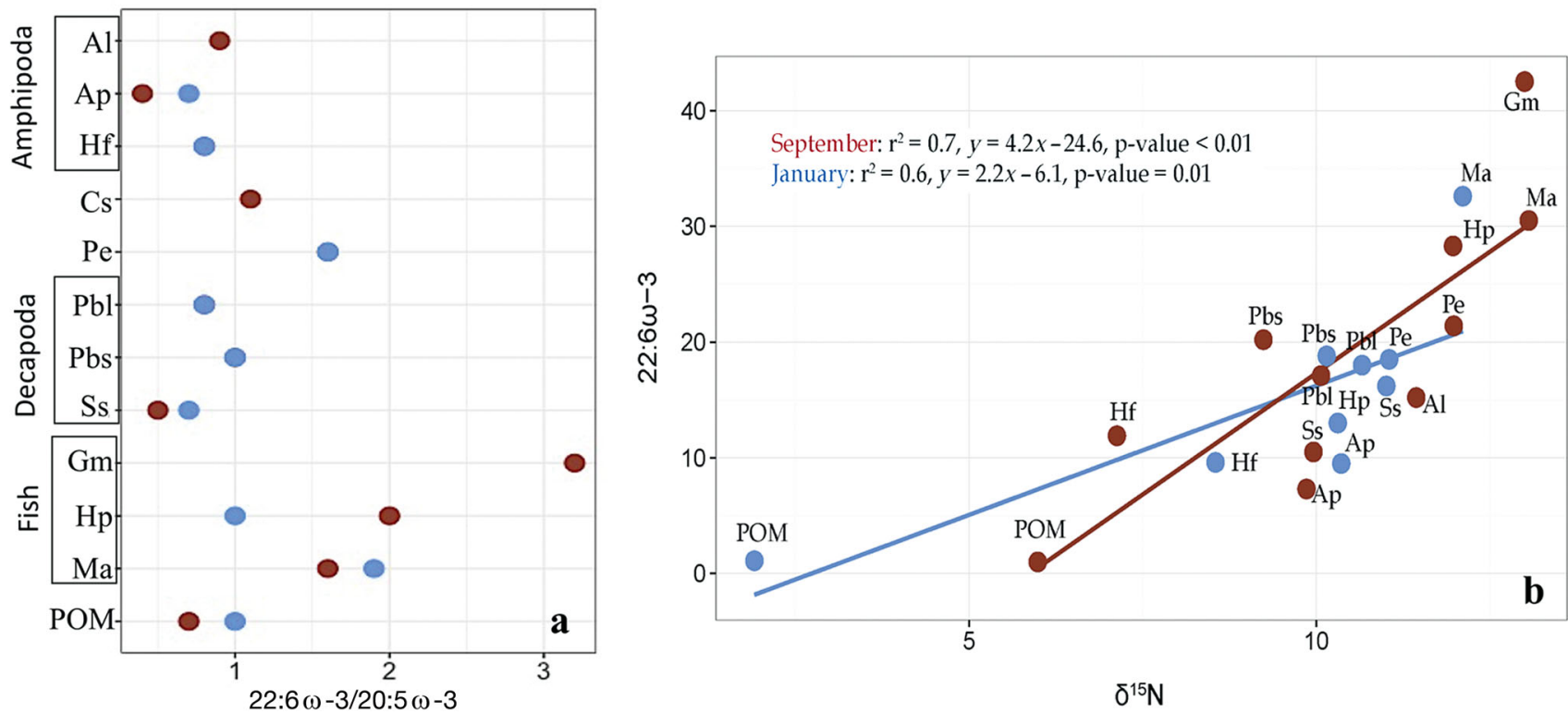

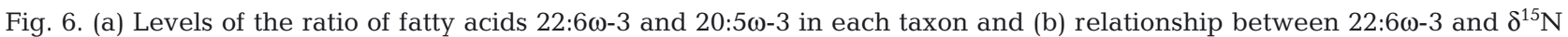
(September: $\mathrm{r}^{2}=0.7, \mathrm{p}<0.01$; January: $\mathrm{r}^{2}=0.6, \mathrm{p}=0.01$ ). Red: September 2014; blue: January 2015. Species abbreviations can be found under 'Label' in Table 3

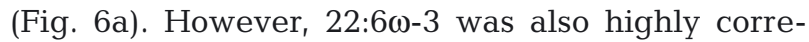
lated with $\delta^{15} \mathrm{~N}$ values, explaining 60 and $70 \%$ of the variance in $\delta^{15} \mathrm{~N}$ in January and September, respectively (Fig. 6b). G. morhua also had the highest levels of C18 PUFAs, a biomarker for dinoflagellates, while bottom water POM and A. phyllonyx had the lowest levels (Fig. 7a).
Levels of the diatom biomarkers (C16 PUFA + 16:1 $\omega-7+20: 5 \omega-3$; Dalsgaard et al. 2003) were highest in S. septemcarinata, totaling almost $30 \%$ of total FAs in both seasons, and lowest in the bottom water POM sample and in G. morhua (Fig. 7b).

The copepod biomarker 20:1 + 22:1 MUFA was highest in $H$. fulvocinctus and $P$. elegans, with values 

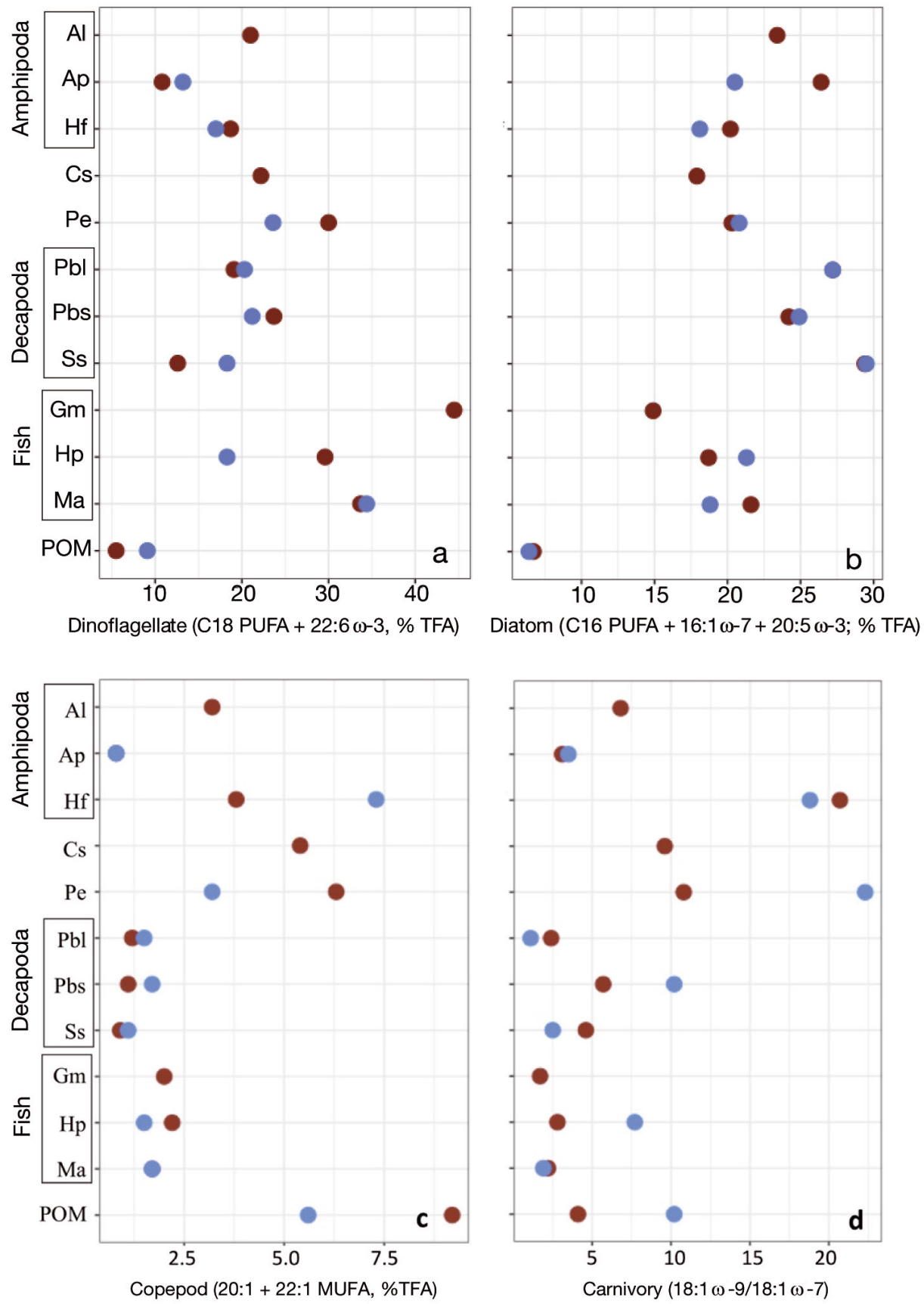

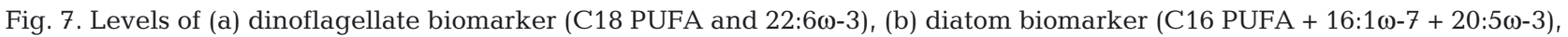
(c) copepod biomarker (20:1 + 22:1 MUFA), and (d) biomarker for carnivorous feeding (ratio of 18:1 $\omega-9 / 18: 1 \omega-7)$ in each taxon. September 2014 samples are in red; January 2015 samples are in blue. Taxon abbreviations on left axis can be found under 'Label' in Table 3

reaching $23 \%$ of total FAs. It was lowest in $G$. morhua and the large size class of $P$. borealis, for which it only constituted about $1.5 \%$ of total FAs (Fig. 7c). P. elegans and H. fulvocinctus both had

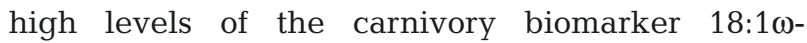
9/18:1 $\omega-7$. P. elegans had a ratio of 6.3 in September and $H$. fulvocinctus had a ratio of 7.3 in January.
Andaniexis lupus also had a high carnivory indicator ratio of 3.2 in September. The Calanus spp. sample had a ratio of 5.4 in September. The bottom water POM had a carnivory indicator ratio of 9.2 in September and 5.6 in January (Fig. 7d).

Levels of $20: 4 \omega-6$, a biomarker for macroalgae, were 3 times higher in A. phyllonyx than other taxa 

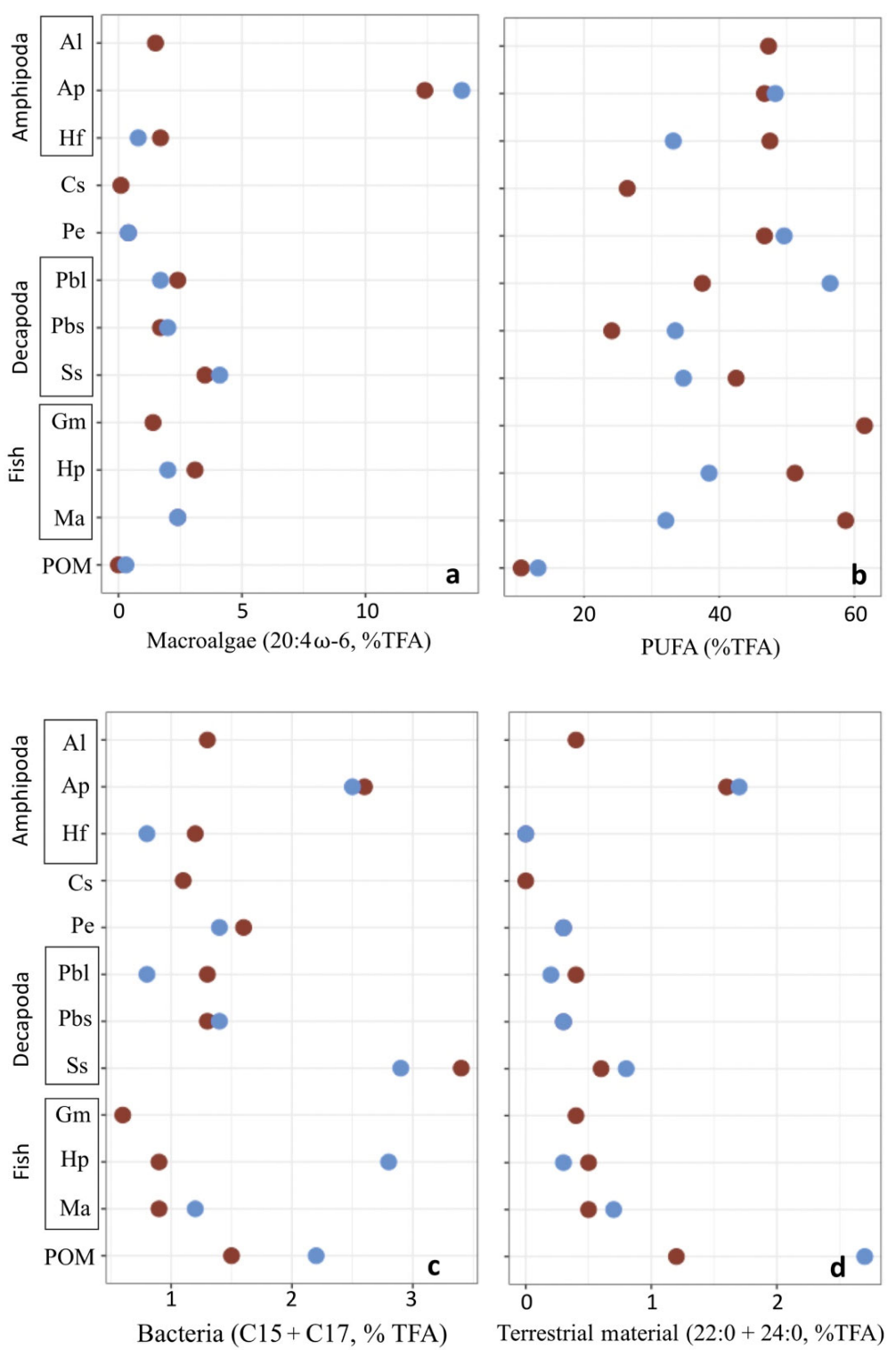

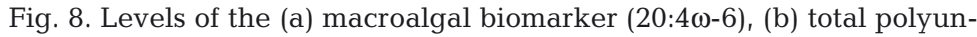
saturated fatty acids (PUFAs), (c) biomarker for bacteria $(\mathrm{C} 15+\mathrm{C} 17)$, and (d) terrestrial material biomarker $(22: 0+24: 0)$, as percent of total fatty acids in each taxon. September 2014 samples are in red; January 2015 samples are in blue. Taxon abbreviations on left axis can be found under 'Label' in Table 3

(Fig. 8a). G. morhua and M. aeglefinus had very high levels of PUFAs at 62 and $59 \%$, respectively. PUFA levels constituted greater than $20 \%$ of total FAs in all biological samples, and ranged from 11 to $13 \%$ in September and January, respectively, for the bottom water POM samples (Fig. 8b). The bacterial biomarker (C15 + C17; Guckert et al. 1985) was highest in S. septemcarinata, A. phyllonyx, bottom water POM, and the January sample of $H$. platessoides (Fig. 8c). The terrestrial vegetation biomarker $(22: 0+24: 0)$ was highest in the bottom water POM sample and in A. phyllonyx (Fig. 8d).

\section{DISCUSSION}

Bottom water POM samples were strongly characterized by the FA 18:0 in both sampling periods (Fig. 4). High levels of 18:0 and other saturated FAs have previously been used to describe a water column in a post-bloom situation (Søreide et al. 2008, Mayzaud et al. 2013a). Fluorescence measurements taken at $38 \mathrm{~m}$ on a mooring in the mouth of Kongsfjord indicate a spring bloom in June in 2014 (F. Cottier pers. comm.). While the bloom may be prolonged to September in some years in Spitzbergen (Eilertsen et al. 1989), POM results reflect that by September 2014 very little fresh phytoplankton was available in the water column. This indicates that sampling in both September and January took place during 'off-bloom' periods in the fjord.

The off-bloom status of the water column may explain the similarity in stable isotope and FA signatures of the hyperbenthic assemblage between September and January. While we found very little difference in carbon sources and trophic structure between the 2 sampling periods, our findings do indicate 2 different food web components in the sampled species assemblage. These 2 components exist along a division in pelagic versus benthic food resources. The division was revealed first by stable isotopes (high vs. low $\delta^{13} \mathrm{C}$ ), and then again by FAs (diatom vs. flagellate biomarkers). The observed division in the hyperbenthic assemblage suggests that while hyperbenthic species occupy the same physical space in the water column, they rely on a variety of carbon sources.

\section{Stable isotopes: benthic vs. pelagic carbon pools}

Stable isotopes of nitrogen are useful for estimating the trophic level of consumers, as tissues are predictably enriched in ${ }^{15} \mathrm{~N}$ by 3 to $4 \%$ relative to the diet (Peterson \& Fry 1987). Stable isotope values of 
carbon changed little between seasons (Fig. 2). However, 10 out of the 11 crustaceans collected had slightly higher values of $\delta^{15} \mathrm{~N}$ in January than in September (Fig. 2). The increase in $\delta^{15} \mathrm{~N}$ could be due to starvation (Ponsard \& Averbuch 1999) or to increased consumption of refractory material (Iken et al. 2010). Increases in $\delta^{15} \mathrm{~N}$ have been noted in sinking phytoplankton due to microbial degradation of chemical compounds (Levinton 1972, Altabet \& McCarthy 1985, Hansen \& Josefson 2004). Therefore, if the crustaceans were to rely more on reworked carbon sources in January relative to September, this could result in the high $\delta^{15} \mathrm{~N}$ values observed here.

Ratios of carbon isotopes change little ( 0.6 to $1 \%$ ) as carbon moves through marine food webs, and can therefore provide useful information concerning an organism's primary carbon sources if these sources have sufficiently different carbon isotope values (Søreide et al. 2006). This study revealed little change, but a wide overall range in $\delta^{13} \mathrm{C}$ between seasons in all taxa, which ranged from -24.4 to $-19.3 \%$. In general, the $\delta^{13} \mathrm{C}$ values of hyperbenthic organisms in this study were lower than values found for the benthic community in Kongsfjord in previous years, suggesting greater reliance on pelagic food sources. Renaud et al. (2011) found $\delta^{13} \mathrm{C}$ values for benthic feeders to range between -20.2 and $-16.9 \%$ in October and July. Similarly, Kędra et al. (2012) reported values for shallow-water benthos to range from -22.5 to $-16.7 \%$ o in winter and -22.5 to $-18.6 \%$ in summer.

While we found no seasonal changes in carbon isotope values, we did find 2 distinct energy channels within this hyperbenthic assemblage, indicating a division between benthic and pelagic feeders. Studies on both higher and lower level consumers have observed $\delta^{13} \mathrm{C}$ to vary due to differential reliance on pelagic versus benthic prey (Hobson et al. 1995, Mincks et al. 2008, Kędra et al. 2012). These studies suggest that the reprocessing of organic matter by bacteria and meiofauna can raise carbon isotopic ratios of consumers considerably. In contrast, a heavy reliance on fresher pelagic primary production by consumers results in lower $\delta^{13} \mathrm{C}$ values in consumer tissues compared with reliance on detrital-based benthic food sources (Hobson et al. 1995, 2002). We found both benthic- and pelagic-feeding species in the Kongsfjord hyperbenthos. Lower $\delta^{13} \mathrm{C}$ values were particularly evident for the highly motile fish and invertebrate species that can migrate into the pelagic. Among these, Syrrhoe crenulata and Thysanoessa inermis were only collected for stable isotopes and seemed to be tightly linked to pelagic production in both seasons. While we did not analyze FAs in $T$. inermis, a recent study of krill in Kongsfjord found the FA profile of $T$. inermis to be consistent with primarily herbivorous feeding, and with a greater reliance on dinoflagellates than diatoms (Huenerlage et al. 2016). Species with high $\delta^{13} \mathrm{C}$ values included Hippoglossoides platessoides, Arrhis phyllonyx, Ancanthostepheia malmgreni, Lebbeus polaris, the large size class of Pandalus borealis, and Sabinea septemcarinata. These species exhibited high values of $\delta^{13} C_{\text {, }}$ which has been previously linked to reworked benthic carbon (Hobson et al. 1995), and seemed to be more reliant on the benthic carbon pool than the rest of the sampled hyperbenthos in both September and January.

\section{Fatty acids: benthic vs. pelagic carbon pools}

The division between benthic and pelagic feeders can be further dissected by their FA profiles. The FAs of each group (benthic vs. pelagic based on $\delta^{13} \mathrm{C}$ ) indicate which carbon sources make up this benthic

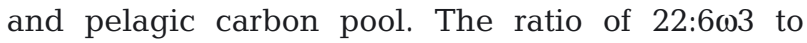
20:5 $\omega 3$ can be used to distinguish between the relative importance of dinoflagellates and diatoms in the diet; a value $>1$ indicates dominance of dinoflagellates, while a value $<1$ suggests a greater relative importance of diatoms (Parrish et al. 2009, Kelly \& Scheibling 2012). This ratio varied widely among taxa, but results suggests the importance of dinoflagellates for the pelagic-feeding species and diatoms for the benthic-feeding species (Figs. 5 \& 6a) It is

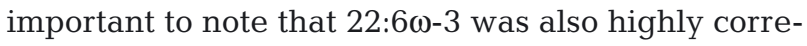
lated with $\delta^{15} \mathrm{~N}$ values, explaining 60 and $70 \%$ of the variance in $\delta^{15} \mathrm{~N}$ in January and September, respec-

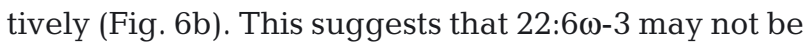
a trustworthy biomarker for dinoflagellates at higher trophic levels, as it tends to biomagnify within the

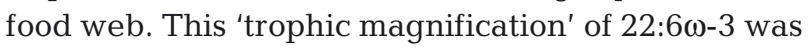
also found for hyperbenthos in the Beaufort Sea (Connelly et al. 2014) and in Newfoundland's Conception Bay (Parrish et al. 2009). Luckily, there are other biomarkers for dinoflagellates that support our finding that pelagic-feeding species rely more on dinoflagellates and benthic-feeding species on diatoms, namely $\mathrm{C} 18$ and C16 PUFAs. Falk-Petersen et al. (1998) found that samples taken from the pelagic zone in the Barents Sea, which were rich in flagellates, contained high levels of C18 PUFAs in addition to $22: 6 \omega-3$, indicating that this could be a useful biomarker for flagellates. This was supported by a recent study in the Svalbard region, which found that POM samples rich in Phaeocystis pouchetii were also 
distinguished by high levels of C18 PUFAs and 22:6 $\omega-3$ (Søreide et al. 2013). In our study, the species with the highest levels of these biomarkers were the same species that had low $\delta^{13} \mathrm{C}$ values (Gadus morhua, Melanogrammus aeglefinus, and Parasagitta elegans). In contrast, levels of diatom biomarkers (C16 PUFA + 16:1 $\omega-7+20: 5 \omega-3$; Dalsgaard et al. 2003) were highest in $S$. septemcarinata, totaling almost $30 \%$ of total FAs in both seasons, and were also high in other species with high $\delta^{13} \mathrm{C}$ values. This finding suggests that dinoflagellates are a key part of the pelagic carbon pool, and diatoms, the benthic carbon pool.

A high level of dinoflagellate or diatom biomarkers in higher trophic levels clearly does not mean that these species are consuming phytoplankton directly. Stomachs of G. morhua and M. aeglefinus contained the euphausiid Thysanoessa spp. and the pelagic amphipod Themisto abyssorum (M. McGovern pers. obs.). Feeding habits of Thysanoessa spp. in Kongsfjord are species-specific. Falk-Petersen et al. (2000) demonstrated that the omnivorous $T$. inermis and $T$. raschii feed mostly on phytoplankton and small copepods, and that $T$. longicaudata feeds more heavily on copepods. T. abyssorum, meanwhile, is a pelagic amphipod known to feed on both diatoms and dinoflagellates as well as copepods (Noyon et al. 2012, Kraft et al. 2013). The phytoplankton biomarkers in fish species sampled here, therefore, likely come from these important omnivorous primary and secondary consumers. It should also be noted that these fish were small individuals. While they were caught using a bottom trawl, these species are known to feed more on pelagic material when they are young (Dalpadado et al. 2009), and switch to a more benthic diet at an older age (Lamond et al. 1998).

The division between benthic- and pelagic-feeding species is further exemplified by the differences observed between the 2 size classes of $P$. borealis. While $P$. borealis is frequently described as a benthic feeder (Shumway et al. 1985), a study in Balsfjord, Norway found distinct differences between size classes, and found the small-sized individuals to be more reliant on pelagic production. Younger individuals were found with only copepods and krill in their stomachs, while stomachs of older individuals also contained mineral particles and occasional remains of benthic polychaetes (Hopkins et al. 1993). Another study in Balsfjord found that older, larger individuals of $P$. borealis spend more time on the bottom than the younger, smaller individuals, and develop a more benthic diet at an older age. This diet shift is related to the sex change from males to females that takes place around age 3 (Nilssen et al. 1986). Results of our study indicate that a similar trend can be found for the P. borealis population in Kongsfjord. In the contribution biplots for both seasons, the large size class was described by large contributions of $20: 5 \omega-3$ and was located closer to A. phyllonyx and $S$. septemcarinata, suggesting this size class relies heavily on benthic carbon. The small size class, meanwhile, had a higher contribution of 22:6 $\omega-3$, indicative of pelagic, dinoflagellate-derived carbon, and was located closer to the samples of $P$. elegans and Halirages fulvocinctus in the CA ordination (Fig. 4). This separation is consistent with the division noted between the more diatom-rich 'benthic' and more flagellate-rich 'pelagic' feeders in this hyperbenthic assemblage.

\section{Pelagic-feeding species}

In addition to the fish, there were several other species relying on pelagic material. The ratio 18:1 $\omega-9 /$ $18: 1 \omega-7$ is used as general indicator of carnivory in benthic animals when it is $>1$ (Sargent \& FalkPetersen 1981, Graeve et al. 1997), and we found high levels in the hyperbenthic carnivores P. elegans and $H$. fulvocinctus (Fig. $7 \mathrm{~d}$ ). These 2 species were grouped together in the CA ordination because they both had high levels of the FAs 20:1 and 22:1 (Fig. 3), FAs that make up a large percentage of the wax esters produced de novo by Calanus copepods (Sargent \& Falk-Petersen 1988). The high levels of the biomarker for carnivory $(18: 1 \omega-9 / 18: 1 \omega-7)$ in $P$. elegans and $H$. fulvocinctus, therefore, are likely due to the consumption of Calanus copepods, which in turn rely on pelagic phytoplankton (Fig. 5). This finding suggests that the conventional phytoplanktoncopepod-chaetognath food web found in the pelagic, and in the hyperbenthic layer in the Beaufort Sea (Connelly et al. 2014), is also found in the hyperbenthos in Kongsfjord. It also indicates that $H$. fulvocinctus is involved in this food web.

This study found no seasonal change in carbon source for $P$. elegans. This chaetognath is a vertical migrator, and likely consumes copepods when it travels through the pelagic on daily and seasonal migrations. Copepods also vertically migrate on daily cycles, and enter diapause at depth during the winter months (Hirche et al. 2015), making them available prey for the hyperbenthic populations of $P$. elegans throughout the year. The movement of both this species and its prey may be responsible for a lack of seasonal change in the predator's ability to feed. 
$H$. fulvocinctus had the highest levels of the copepod biomarker across seasons (Fig. 7c) of any other species. At the same time, their $\delta^{15} \mathrm{~N}$ value was the lowest of all taxa in both seasons, and was quite similar to the values for the euphausiid $T$. inermis (Fig. 2). Calanus copepods are known to diapause at depth in large densities during winter, so they may be easy prey for hyperbenthic carnivores during the winter months (Darnis et al. 2012). Additionally, $H$. fulvocinctus may scavenge dead Calanus or chaetognath debris, which would also lead to high levels of the zooplankton biomarkers in its tissues.

\section{Benthic-feeding species}

A. phyllonyx and S. septemcarinata were tightly grouped in the CA ordination (Fig. 4) by their high signatures of diatom biomarkers (C16 PUFA + 16:1 $\omega-6$ $+20: 5 \omega-3$; Dalsgaard et al. 2003), suggesting that diatoms are an important part of the benthic carbon pool described by more enriched $\delta^{13} \mathrm{C}$ values. However, there are indications that the benthic carbon pool described by the stable isotope data is highly diverse, with macroalgae and terrestrial material also playing a key role.

A. phyllonyx, known as a deposit-feeder/predator Legeżyńska et al. 2012), was distinctly different from other taxa in its high levels of arachidonic acid

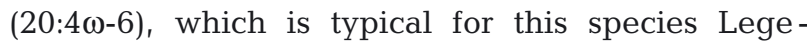
żyńska et al. 2012, Connelly et al. 2014). Arachidonic

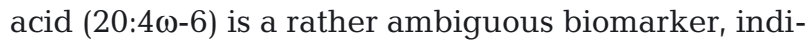
cating macroalgae (Graeve et al. 2001, Nyssen et al. 2005), diatoms, microbial eukaryotes, terrestrial matter (Sargent et al. 1987, Howell et al. 2003), and foraminifera (Gooday et al. 2002, Suhr et al. 2003), making it difficult to draw conclusions.

Analysis of stomach contents of $A$. phyllonyx has suggested a diet rich in foraminifera supplemented with Polychaeta, Halacaroidea (Acari) and Sipuncula (Legeżyńska et al. 2012). However, the close positioning of A. phyllonyx and the macroalgal samples on the September contribution biplot (Fig. 3), as well as high levels of the bacterial biomarker (Fig. 8c), suggest that macroalgal detritus is likely the main source of carbon for this species in our study region. A. phyllonyx was also enriched in the FA biomarker for terrestrial material (Fig. 8d). There are 3 tidewater glaciers and several rivers that drain into Kongsfjord, and terrestrial carbon does seem to contribute partly to this species' carbon supply.

S. septemcarinata, meanwhile, appears to rely on detritus of phytoplankton origin. This species was also higher in $\delta^{15} \mathrm{~N}$ compared with other species, and was grouped with $A$. phyllonyx on the contribution biplot (Fig. 4), most likely due to the high levels of the bacterial biomarker 18:1 $\omega-7$. However, levels of

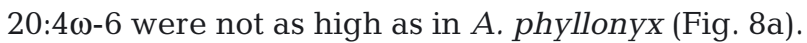
The FA profile of $S$. septemcarinata had a higher percentage of the diatom biomarker 20:5 $\omega$-3 (Fig. 5b) relative to other species. This, combined with high contributions of the bacterial biomarker 18:1 $\omega-7$, may reject direct feeding on bacteria taken with phytodetritus or the consumption of small, bacterivorous organisms (Volkman et al. 1980). Results of our study suggest that both diatoms and flagellates are important food sources for the hyperbenthic community. However, diatoms may be more important for bottom-feeders and flagellates more important for the species which can actively feed in the pelagic realm.

\section{Lipid reserves and isotopic turnover}

While stable isotope and FA profiles, discussed above, reflect the consumption of pelagic and benthic carbon by these hyperbenthic species, it is difficult to know when this feeding took place. Results of laboratory experiments have found that the turnover time of stable isotopes in non-lipid tissue in Calanus glacialis was unaffected by prolonged periods of starvation and reflected that of previously consumed food (Tamelander et al. 2006).

While some species may use their lipid reserves to survive the unproductive dark season, there is no reason to believe that it is the dominant strategy for hyperbenthic species in Kongsfjord. A study on benthic amphipods around Svalbard found that lipid storage was not a strategy for surviving the winter, but rather their fluctuation coincided with reproductive seasonality. They also found stomachs full of various food items during the winter months (Legeżyńska et al. 2012). Similarly, seasonal cycles of total lipid content in benthic shrimp and prawn species have been attributed to gametogenesis, rather than to fluctuations in food availability (Clarke 1977, 1979). Detected diel vertical migration of zooplankton (Grenvald et al. 2016) indicate that at least several zooplankton taxa are active and expend energy during the polar night. The fjord itself is highly advective, with a large volume of Atlantic water entering the fjord from the shelf (Cottier et al. 2005), likely bringing some organic material with it. The availability of such resources to the hyperbenthos would be enhanced by the ability of these species to migrate into the pelagic zone. 
While activity levels suggest the necessity of feeding during the dark months, it may be that consumption levels are not high enough to replace isotopic signatures and FAs in consumer tissues. Essentially, enough energy is attained for general maintenance, but not enough for storage, meaning that tissues would still reflect the signatures of food consumed during the last period of high production. However, there were subtle differences between the September and January results that may indicate that species are feeding and assimilating their food. Results indicate an increase in bacterial biomarkers in January for several taxa, accompanied by a decrease in PUFA levels for some species. Enrichment in $\delta^{15} \mathrm{~N}$ in January was also observed, which has been attributed to increased consumption of reworked material (Iken et al. 2010). Furthermore, these trends were noted for small taxa, including the amphipods and decapods, which have more rapid turnover of major lipid components (over 2 to 3 wk; Graeve et al. 1994), and not for large taxa like fish, which are subject to slower biochemical turnover rates. These subtle trends in the results may indicate the importance of microbial-detrital carbon pools in 'off-bloom' situations. However, January sampling may be too soon for these potential food sources to be more clearly reflected in biomarker values.

\section{IMPLICATIONS AND CONCLUSIONS}

Ecosystem-level implications of our results lie in the potential role hyperbenthic organisms play as a connection between the pelagic and benthic realms. Previous studies have suggested that the utilization of multiple energy channels by higher trophic levels can help stabilize an ecosystem characterized by pulses in food availability (Rooney \& McCann 2012, McMeans et al. 2013). Our results suggest that the hyperbenthos may facilitate this process by repackaging both benthic and pelagic carbon and actively dispersing these through the water column. Hyperbenthic communities include important prey species for commercial fish including Atlantic cod and haddock (Parsons et al. 1998). Hyperbenthic species that consume benthic carbon can therefore effectively transfer energy from the benthos to the pelagic when they are consumed by fish, either at depth or during their daily and seasonal migrations to the pelagic. Species consuming detritus (Arrhis phyllonyx, Sabinea septemcarinata) and benthic invertebrates (Pandalus borealis) would effectively transfer detrital and benthic carbon to the pelagic food web. Like- wise, several of these hyperbenthic taxa may also aid in pelagic-benthic coupling. The position of these organisms just above the seafloor, with pelagic carbon in their guts, may facilitate the export flux of phytoplankton production to depth. This is relevant for both daily and seasonal vertical migrators. For example, copepods that over-winter at depth are within reach of benthic or epibenthic feeders, who may benefit from this additional carbon source during the winter months. Therefore, higher trophic level species feeding on hyperbenthic taxa receive carbon from a highly diverse carbon pool, which may stabilize food resources throughout the year in a system characterized by extreme pulses in primary production.

Thus, the hyperbenthic layer, a vastly understudied portion of the water column, may play an underappreciated role in the mobilization of carbon, both spatially and temporally. The utilization of different carbon sources by different parts of the hyperbenthos tightens the connection between benthic and pelagic layers via benthic-pelagic and pelagic-benthic coupling. In addition, by packaging and mobilizing carbon through different energy channels to higher trophic levels, the hyperbenthic assemblage sampled here plays an important role in stabilizing food availability throughout the year.

Acknowledgements. We thank Akvaplan-niva, UNIS, UiT, and the Fulbright Foundation as well as fellow members of the Marine Night Project and the crew of the 'Helmer Hansen'. Specifically, thanks to Joanna Legeżyńska, Mikołaj Mazurkiewicz, and Maria Włodarska-Kowalczuk for help collecting samples in January 2015. Additional thanks to Tara Connelly for her help interpreting the fatty acid data, Joanna Legeżyńska for comments on the final manuscript, and to Karol Kulinski for overseeing the stable isotope analysis in Sopot. We thank Colin Griffiths and Finlo Cottier for overseeing the SAMS mooring programme supported by the UK Natural Environment Research Council (Oceans 2025) and the Research Council of Norway (projects Cleopatra II: 216537, and Circa: 214271/F20). Special thanks to Raul Primicerio and Michael Greenacre for help with statistics. Significant funding was provided by the Norwegian Research Council (Marine Night Project, Project No. 226417)

\section{LITERATURE CITED}

Altabet M, McCarthy J (1985) Temporal and spatial variations in the natural abundance of ${ }^{15} \mathrm{~N}$ in PON from a warm-core ring. Deep-Sea Res A, Oceanogr Res Pap 32: $755-772$

Ambrose WG, Renaud PE (1995) Benthic response to water column productivity patterns: evidence for benthicpelagic coupling in the Northeast Water Polynya. J Geophys Res 100:4411-4421 
Budge SM, Parrish CC (1998) Lipid biogeochemistry of plankton, settling matter and sediments in Trinity Bay, Newfoundland. II. Fatty acids. Organic Geochem 29: 1547-1559

Christie WW (1982) Lipid analysis, 2nd edn. Pergamon Press, New York, NY

Clarke A (1977) Lipid class and fatty acid composition of Chonsmus antarcticus (Pfeffer) (Crustacea: Decapoda) at South Georgia. J Exp Mar Biol Ecol 28:297-314

Clarke A (1979) Lipid content and composition of the pink shrimp, Pandalus montagui (Crustacea: Decapoda). J Exp Mar Biol Ecol 38:1-17

* Connelly TL, Deibel D, Parrish CC (2014) Trophic interactions in the benthic boundary layer of the Beaufort Sea shelf, Arctic Ocean: combining bulk stable isotope and fatty acid signatures. Prog Oceanogr 120:79-92

Cottier FR, Tverberg V, Inall M, Svendsen H, Nilsen F, Griffiths C (2005) Water mass modification in an Arctic fjord through cross-shelf exchange: the seasonal hydrography of Kongsfjorden, Svalbard. J Geophys Res 110:C12005

Walpadado P, Bogstad B, Eriksen E, Rey L (2009) Distribution and diet of 0-group cod (Gadus morhua) and haddock (Melanogrammus aeglefinus) in the Barents Sea in relation to food availability and temperature. Polar Biol 32:1583-1596

Dalsgaard J, St. John M, Kattner G, Müller-Navarra D, Hagen W (2003) Fatty acid trophic markers in the pelagic marine environment. Adv Mar Biol 46:225-340

Darnis G, Fortier L (2012) Zooplankton respiration and the export of carbon at depth in the Amundsen Gulf (Arctic Ocean). J Geophys Res 117:C04013

* Darnis G, Robert D, Pomerleau C, Link H, Archambault P, Nelson RJ (2012) Current state and trends in Canadian Arctic marine ecosystems: II. Heterotrophic food web, pelagic-benthic coupling, and biodiversity. Clim Change 115:179-205

* Dauvin JC, Vallet C (2006) The near bottom layer as an ecological boundary in marine ecosystems: diversity, taxonomic composition and community definitions. Hydrobiologia 555:49-58

* Eilertsen HC, Taasen JP, Węsławski JM (1989) Phytoplankton studies in the fjords of West Spitsbergen: physical environment, production in spring and summer. J Plankton Res 11:1245-1260

Falk-Petersen S, Sargent JR, Henderson J, Hagseth EN, Hop H, Okolodkov YB (1998) Lipids and fatty acids in ice algae and phytoplankton from the marginal ice zone in the Barents Sea. Polar Biol 20:41-47

Falk-Petersen S, Hagen W, Kattner G, Clarke A, Sargent J (2000) Lipids, trophic relationships, and biodiversity in Arctic and Antarctic krill. Can J Fish Aquat Sci 57: 178-191

Folch J, Lees M, Sloane-Stanley GH (1957) A simple method for the isolation and purification of total lipids from animal tissues. J Biol Chem 226:497-509

*Gooday AJ, Pond DW, Bowser SS (2002) Ecology and nutrition of the large agglutinated foraminiferan Bathysiphon capillare in the bathyal NE Atlantic: distribution within the sediment profile and lipid biomarker composition. Mar Ecol Prog Ser 245:69-82

* Graeve M, Kattner G, Piepenburg D (1997) Lipids in Arctic benthos: Does fatty acid and alcohol composition reflect feeding and trophic interactions? Polar Biol 18:53-61

Graeve M, Kattner G, Hagen W (1994) Diet-induced changes in the fatty acid composition of Arctic herbivorous cope- pods: experimental evidence of trophic markers. J Exp Mar Biol Ecol 182:97-110

Graeve M, Dauby P, Scailteur Y (2001) Combined lipid, fatty acid and digestive tract content analyses: a penetrating approach to estimate feeding modes of Antarctic amphipods. Polar Biol 24:853-862

Gaf G, Rosenberg R (1997) Bioresuspension and biodeposition: a review. J Mar Syst 11:269-278

* Grebmeier JM, Barry JP (1991) The influence of oceanographic processes on pelagic-benthic coupling in polar regions: a benthic perspective. J Mar Syst 2:495-518

Greenacre M, Primicerio R (2013) Multivariate analysis of ecological data. Fundacion BBVA, Bilbao

* Grenvald J, Callesen TA, Daase M, Hobbs L and others (2016) Plankton community composition and vertical migration during polar night in Kongsfjorden. Polar Biol 39:1879-1895

Guckert JB, Antworth CP, Nichols PD, White DC (1985) Phospholipid, ester-linked fatty acid profiles as reproducible assays for changes in prokaryotic community structure of estuarine sediments. FEMS Microbiol Ecol 31:147-158

Hansen HØ, Aschan M (2000) Growth, size- and age-atmaturity of shrimp, Pandalus borealis, at Svalbard related to environmental parameters J Northwest Atl Fish Sci 27:83-91

*Hansen J, Josefson A (2004) Ingestion by deposit-feeding macro-zoobenthos in the aphotic zone does not affect the pool of live pelagic diatoms in the sediment. J Exp Mar Biol Ecol 308:59-84

Hirche HJ, Laudien J, Buchholz F (2015) Near-bottom zooplankton aggregations in Kongsfjorden: implications for pelago-benthic coupling. Polar Biol 39:1897-1912

*Hobson KA, Ambrose WG Jr, Renaud PE (1995) Sources of primary production, benthic-pelagic coupling, and trophic relationships within the Northeast Water Polynya: insights from $\delta^{13} \mathrm{C}$ and $\delta^{15} \mathrm{~N}$ analyses. Mar Ecol Prog Ser 128:1-10

*Hobson KA, Fisk A, Karnovsky NJ, Holst M, Gagon JM, Fortier $M(2002)$ A stable isotope $\left(\delta^{13} \mathrm{C}, \delta^{15} \mathrm{~N}\right)$ model for the North Water food web: implications for evaluating trophodynamics and the flow of energy and contaminants. Deep-Sea Res II 49:5131-5150

*Hopkins CCE, Sargent JR, Nilssen EM (1993) Total lipid content and lipid and fatty acid composition of the deepwater prawn Pandalus borealis from Balsfjord, northern Norway: growth and feeding relationships. Mar Ecol Prog Ser 96:217-228

*Hostens K, Mees J (1999) The mysid-feeding guild of demersal fishes in the brackish zone of the Westerschelde estuary. J Fish Biol 55:704-719

Howell Kl, Pond DW, Billett DSM, Tyler PA (2003) Feeding ecology of deep-sea seastars (Echinodermata: Asteroidea): a fatty-acid biomarker approach. Mar Ecol Prog Ser 255:193-206

*Huenerlage K, Graeve M, Buchholz C, Buchholz F (2016) Lipid composition and trophic relationships of krill species in a high Arctic fjord. Polar Biol 39:1803-1817

* Iken K, Bluhm BA, Dunton K (2010) Benthic food-web structure under differing water mass properties in the southern Chukchi Sea. Deep-Sea Res II 57:71-85

IPCC (2013) Climate change 2013: the physical science basis. Contribution of Working Group I to the Fifth Assessment Report of the Intergovernmental Panel on Climate Change. Cambridge University Press, Cambridge 
Johannessen OM, Bengtsson L, Miles MW, Kuzmina SI and others (2004) Arctic climate change: observed and modeled temperature and sea ice variability. Tellus, Ser A, Dyn Meterol Oceanogr 56:559-560

Kędra M, Kuliński K, Walkusz W, Legeżyńska J (2012) The shallow benthic food web structure in the high Arctic does not follow seasonal changes in the surrounding environment. Estuar Coast Shelf Sci 114:183-191

Kelly JR, Scheibling RE (2012) Fatty acids as dietary tracers in benthic food webs. Mar Ecol Prog Ser 446:1-22

Klemetsen A (1982) Food and feeding habit of cod from Balsfjord, northern Norway during a one-year period. J Cons Cons Int Explor Mer 40:101-111

Kortsch S, Primicerio R, Fossheim M, Dolgov AV, Aschan M (2015) Climate change alters the structure of Arctic marine food webs due to poleward shifts of boreal generalists. Proc R Soc B 282:20151546

Koulouri P, Dounas C, Eleftheriou A (2013) Hyperbenthic community structure over oligotrophic continental shelves and upper slopes: Crete (South Aegean Sea, NE Mediterranean). Estuar Coast Shelf Sci 117:188-198

Kraft A, Berge J, Varpe Ø, Falk-Peterson S (2013) Feeding in Arctic darkness: mid-winter diet of the pelagic amphipods Themisto abyssorum and T. libellula. Mar Biol 160: 241-248

Lamond T, Schneider D, Methven D (1998) Transition from pelagic to benthic prey for age group 0-1 Atlantic cod, Gadus morhua. Fish Bull 96:908-911

KLegeżyńska J (2008) Food resource partitioning among Arctic sublittoral lysianassoid amphipods in summer. Polar Biol 31:663-670

光Legeżyńska J, Kędra M, Walkusz W (2012) When season does not matter: summer and winter trophic ecology of Arctic amphipods. Hydrobiologia 684:189-214

* Legeżyńska J, Kędra M, Walkusz W (2014) Identifying trophic relationships within the high Arctic benthic community: How much can fatty acids tell? Mar Biol 161: 821-836

Levinton J (1972) Stability and trophic structure in depositfeeding and suspension-feeding communities. Am Nat 106:472-486

Mayzaud P, Boutoute M, Gasparini S (2013a) Differential response of fatty acid composition in the different lipid classes from naturally occurring particulate matter during spring and summer in a high Arctic fjord (Kongsfjorden, Svalbard). Mar Chem 151:23-34

Mayzaud P, Boutoute M, Noyon M, Narcy F, Gasparini S (2013b) Lipid and fatty acids in naturally occurring particulate matter during spring and summer in a high Arctic fjord (Kongsfjorden, Svalbard). Mar Biol 160: 383-398

McMeans BC, Rooney N, Arts MT, Fisk AT (2013) Food web structure of a coastal Arctic marine ecosystem and implications for stability. Mar Ecol Prog Ser 482:17-28

Mees J, Jones M (1997) The hyperbenthos. Oceanogr Mar Biol Annu Rev 35:221-255

Mincks S, Smith C, Jeffreys R, Sumida P (2008) Trophic structure on the West Antarctic Peninsula shelf: detritivory and benthic inertia revealed by $\delta^{13} \mathrm{C}$ and $\delta^{15} \mathrm{~N}$ analysis. Deep-Sea Res II 55:2502-2514

Morata N, Renaud PE (2008) Sedimentary pigments in the western Barents Sea: A reflection of pelagic-benthic coupling? Deep-Sea Res II 55:2381-2389

Nelson MM, Mooney B, Nichols JD, Phleger CF (2001) Lipids of Antarctic Ocean amphipods: food chain inter- actions and the occurrence of novel biomarkers. Mar Chem 73:53-64

Nilssen E, Larsen R, Hopkins C (1986) Catch and size selection of Pandalus borealis in a bottom trawl and implications for population dynamics analyses. ICES CM 1986/ $\mathrm{K}: 4$

Nishino S, Kikuchi T, Yamamoto-Kawai M, Kawaguchi Y, Hirawake T, Itoh M (2011) Enhancement/reduction of biological pump depends on ocean circulation in the seaice reduction regions of the Arctic Ocean. J Oceanogr 67 : 305-314

* Noyon M, Narcy F, Gasparini S, Mayzaud P (2012) Ontogenic variations in fatty acid and alcohol composition of the pelagic amphipod Themisto libellula in Kongsfjord (Svalbard). Mar Biol 159:805-816

*Nyssen F, Brey T, Dauby P, Graeve M (2005) Trophic position of Antarctic amphipods-enhanced analysis by a 2-dimensional biomarker assay. Mar Ecol Prog Ser 300: $135-145$

Oksanen J, Guillaume Blanchet F, Friendly M, Kindt R and others (2017) vegan: community ecology package. R package version 2.4-4. https://CRAN.R-project.org/ package=vegan

* Parrish CC, Deibel D, Thompson RJ (2009) Effect of sinking spring phytoplankton blooms on lipid content and composition in suprabenthic and benthic invertebrates in a cold ocean coastal environment. Mar Ecol Prog Ser 391: 33-51

* Parsons DG, Colbourne EB, Lilly GR, Kulka DW (1998) Northern shrimp (Pandalus borealis) on Flemish Cap (NAFO Division 3M) - oceanography, fishery and biology. J Northwest Atl Fish Sci 24:1-26

Peterson BJ, Fry B (1987) Stable isotopes in ecosystem studies. Annu Rev Ecol Syst 18:293-320

* Ponsard S, Averbuch P (1999) Should growing and adult animals fed on the same diet show different $\delta^{15} \mathrm{~N}$ values? Rapid Commun Mass Spectrom 13:1305-1310

Renaud PE, Tessmann M, Evenset A, Christensen GN (2011) Benthic food-web structure of an Arctic fjord (Kongsfjorden, Svalbard). Mar Biol Res 7:13-26

Renaud PE, Løkken TS, Jørgensen LL, Berge J, Johnson BJ (2015) Macroalgal detritus and food-web subsidies along an Arctic fjord depth-gradient. Front Mar Sci 2:31

Reuss N, Poulsen L (2002) Evaluation of fatty acids as biomarkers for a natural plankton community. A field study of a spring bloom and a post-bloom period off West Greenland. Mar Biol 141:423-434

* Rooney N, McCann KS (2012) Integrating food web diversity, structure and stability. Trends Ecol Evol 27: $40-46$

Rudstam LG, Hansson S, Larsson U (1986) Abundance, species composition and production of mysid shrimps in a coastal area of the northern Baltic proper. Ophelia 4: 225-238

* Sargent JR, Falk-Petersen S (1981) Ecological investigations on the zooplankton community in Balsfjorden, northern Norway: lipids and fatty acids in Meganyctiphanes norvegica, Thysanoessa raschi and $T$. inermis during midwinter. Mar Biol 62:131-137

* Sargent JR, Falk-Petersen S (1988) The lipid biochemistry of calanoid copepods. Hydrobiologia 167-168:101-114

Sargent JR, Parkes RJ, Mueller-Harvey I, Henderson RJ (1987) Lipid biomarkers in marine ecology. In: Sleigh MA (ed) Microbes in the sea. Ellis Horwood, Chichester, p 119-138 
Shumway SE, Perkins HC, Schick DF, Stickney AP (1985) Synopsis of biological data on the pink shrimp, Pandalus borealis Krøyer, 1838. FAO Fish Synop 144:1-57

Søreide JE, Hop H, Carrol ML, Falk-Petersen S, Hegseth EN (2006) Seasonal food web structures and sympagicpelagic coupling in the European Arctic revealed by stable isotopes and a two-source food web model. Prog Oceanogr 71:59-87

Søreide J, Falk-Petersen S, Hegseth E, Hop H, Carroll ML, Hobson K, Błachowiak-Samołyk K (2008) Seasonal feeding strategies of Calanus in the high-Arctic Svalbard region. Deep-Sea Res II 55:2225-2244

Søreide J, Carroll ML, Hop H, Ambrose W, Hegseth E, FalkPetersen S (2013) Sympagic-pelagic-benthic coupling in Arctic and Atlantic waters around Svalbard revealed by stable isotopic and fatty acid tracers. Mar Biol Res 9: 831-850

Suhr SB, Pond DW, Gooday AJ, Smith CR (2003) Selective feeding by benthic foraminifera on phytodetritus on the western Antarctic Peninsula shelf: evidence from fatty acid biomarker analysis. Mar Ecol Prog Ser 262:153-162

* Tamelander T, Søreide JE, Hop H, Carroll ML (2006) Fractionation of stable isotopes in the Arctic marine copepod Calanus glacialis: effects on the isotopic composition of marine particulate organic matter. J Exp Mar Biol Ecol 333:231-240

* Volkman JK, Johns RB, Gillan FT, Perry GJ, Bavor HJ Jr (1980) Microbial lipids of an intertidal sediment-I. Fatty acids and hydrocarbons. Geochim Cosmochim Acta 44: 1133-1143

\section{Appendix}

Table A1. Stable isotope reults with standard deviations for both January and September. The map \# corresponds with the station number on the map in Fig. 1. See Table 3 for full species names

\begin{tabular}{|c|c|c|c|c|c|c|c|c|c|}
\hline & \multicolumn{4}{|c|}{ September } & & \multicolumn{4}{|c|}{ January } \\
\hline Taxon & Map \# & $\mathbf{n}$ & $\delta^{15} \mathbf{N}[\% 0]$ & $\delta^{13} \mathrm{C}[\%$ & Taxon & Map \# & $\mathbf{n}$ & $\delta^{15} \mathbf{N}[\% 0]$ & $\delta^{13} \mathrm{C}[\% 0]$ \\
\hline A. malmgreni & 9 & 1 & 10.1 & -20.2 & A. malmgreni & 20 & 2 & $11.2(0.2)$ & $-20.5(0.8)$ \\
\hline A. lupus & 6 & 2 & $11.4(0.2)$ & $-21.0(0.3)$ & A. lupus & 14 & 1 & 12.1 & -21.0 \\
\hline A. phyllonyx & 6 & 5 & $9.8(0.4)$ & $-19.8(0.3)$ & A. phyllonyx & 10 & 3 & $10.1(0.2)$ & $-19.4(0.5)$ \\
\hline Calanus spp. & 5 & & & & A. phyllonyx & 14 & 3 & $10.4(0.5)$ & $-20.0(0.5)$ \\
\hline D. aculeata & 6 & & & & A. phyllonyx & 22 & 3 & $10.5(0.1)$ & $-20.2(0.1)$ \\
\hline E. erythropthalma & 2 & 2 & $10.2(0.6)$ & $-21.4(1.4)$ & A. phyllonyx & 21 & 3 & $10.5(0.1)$ & $-19.9(0.6)$ \\
\hline G. morhua & 1 & 5 & $13.0(0.6)$ & $-21.4(0.3)$ & A. phyllonyx & 20 & 3 & $10.4(0.3)$ & $-20.1(1.3)$ \\
\hline H. fulvocinctus & 6 & 3 & $7.1(0.3)$ & $-20.4(0.4)$ & B. saida & 13 & 5 & $11.2(0.4)$ & $-23.8(0.6)$ \\
\hline H. platessoides & 1 & 3 & $12.0(0.7)$ & $-19.9(0.6)$ & B. saida & 18 & 3 & $12.0(0.5)$ & $-20.7(0.2)$ \\
\hline L. digitata & 6 & & & & E. erythropthalma & 14 & 4 & $10.3(0.2)$ & $-21.0(0.7)$ \\
\hline L. polaris & 6 & 3 & $7.6(1.1)$ & $-20.2(1.2)$ & E. erythropthalma & 14,20 & 2 & $10.8(0.2)$ & $-21.0(0.8)$ \\
\hline M. aeglefinus & 1 & 5 & $13.1(0.8)$ & $-20.6(0.5)$ & H. fulvocinctus & $14,21,22$ & 3 & $8.6(0.0)$ & $-21.5(0.7)$ \\
\hline P. borealis (large) & 6 & 3 & $10.0(0.9)$ & $-20.8(0.3)$ & H. platessoides & 13 & 2 & $10.3(0.0)$ & $-21.3(0.1)$ \\
\hline P. borealis (large) & 8 & 3 & $10.2(0.4)$ & $-20.8(0.4)$ & L. polaris & 22 & 1 & 10.1 & -20.4 \\
\hline P. borealis (small) & 6 & 3 & $9.0(1.1)$ & $-21.1(0.4)$ & L. maculatus & 11 & 2 & $10.0(0.5)$ & $-22.7(0.3)$ \\
\hline P. borealis (small) & 8 & 2 & $9.5(0.6)$ & $-21.7(0.6)$ & L. maculatus & 18 & 3 & $10.5(0.1)$ & $-21.9(0.4)$ \\
\hline P. elegans & 5 & & & & M.aeglefinus & 13 & 4 & $12.1(0.4)$ & $-21.4(1.4)$ \\
\hline P. elegans & 3 & 1 & 11.0 & -23.4 & P. borealis (large) & 14 & 4 & $10.3(0.3)$ & $-20.1(0.5)$ \\
\hline P. elegans & 6 & 1 & 12.9 & -20.7 & P. borealis (large) & 18 & 4 & $10.7(0.6)$ & $-20.3(0.4)$ \\
\hline R. confervoides & 6 & & & & P. borealis (large) & 10 & 4 & $11.0(0.6)$ & $-19.9(0.3)$ \\
\hline S. septemcarinata & 3 & 3 & $10.0(1)$ & $-21.7(1.1)$ & P. borealis (small) & 14 & 4 & $9.9(0.5)$ & $-21.4(0.4)$ \\
\hline S. crenulata & 6 & 2 & $8.6(0.1)$ & $-23.2(1.2)$ & P. borealis (small) & 10 & 4 & $10.0(0.5)$ & $-21.5(0.3)$ \\
\hline T. inermis & 3 & 1 & 8.8 & -22.9 & P. borealis (small) & 18 & 4 & $10.5(0.2)$ & $-21.2(0.2)$ \\
\hline Bottom water POM & 4 & 3 & $4.5(1.2)$ & $-23.2(0.2)$ & P. elegans & 11 & 3 & $10.9(0.6)$ & $-23.5(2.4)$ \\
\hline Bottom water POM & 7 & 3 & $7.5(1.2)$ & $-22.8(0.1)$ & P. elegans & 10 & 3 & $11.2(0.8)$ & $-21.9(1.2)$ \\
\hline & & & & & S. septemcarinata & 14 & 3 & $10.5(0.4)$ & $-20.3(0.8)$ \\
\hline & & & & & S. septemcarinata & 13 & 3 & $11.1(0.3)$ & $-20.7(1.0)$ \\
\hline & & & & & S. septemcarinata & 21 & 3 & $11.4(1.0)$ & $-19.3(1.2)$ \\
\hline & & & & & S. crenulata & 14 & 1 & 9.2 & -24.4 \\
\hline & & & & & T. inermis & 10 & 2 & $8.2(0.3)$ & $-22.6(1.6)$ \\
\hline & & & & & Bottom water POM & 12 & 3 & $1.3(1.2)$ & $-23.7(0.3)$ \\
\hline & & & & & Bottom water POM & 17 & 3 & $1.5(1.2)$ & $-24.2(0.7)$ \\
\hline & & & & & Bottom water POM & 23 & 3 & $2.9(0.3)$ & $-24.3(2.0)$ \\
\hline
\end{tabular}


Table A2. Dominating fatty atty acids (with standard deviation) for both September and January. Fatty acid levels are shown as percent of total fatty acid. The map \# corresponds with the station number on the map in Fig. 1. Combined samples are noted by multiple stations listed under 'Map \#'. See Table 3 for full species names

\begin{tabular}{|c|c|c|c|c|c|c|c|c|}
\hline & \multicolumn{8}{|c|}{ September } \\
\hline Taxon & Map \# & $\mathbf{n}$ & $22: 6 \omega-3$ & $20: 5 \omega-3$ & $18: 1 \omega-9$ & $16: 1 \omega-7$ & 18:0 & $20: 4 \omega-6$ \\
\hline A. lupus & 6 & 2 & $15.2(1.7)$ & $16.8(0.8)$ & $14.8(0.6)$ & $5.7(1.3)$ & $1.2(0.1)$ & $1.5(0.3)$ \\
\hline A. phyllonyx & 6 & 3 & $7.3(0.2)$ & $16.5(1.6)$ & $8.4(0.1)$ & $8.8(0.9)$ & $1.8(0.1)$ & $12.4(1.1)$ \\
\hline Calanus spp. & 5 & 3 & $11.5(1.7)$ & $10.2(0.4)$ & $4.3(0.1)$ & $6.2(0.9)$ & $5.9(1.3)$ & $0.1(0.2)$ \\
\hline D. aculeata & 6 & 1 & 1.4 & 8.3 & 9.8 & 2.1 & 1.7 & 14.9 \\
\hline G. morhua & 1 & 3 & $42.5(1.7)$ & $13.1(1.0)$ & $6(0.6)$ & $1.2(0.2)$ & $3.9(0.1)$ & $1.4(0.1)$ \\
\hline H. fulvocinctus & 6 & 3 & $11.9(2.1)$ & $14.4(2.2)$ & $10.7(1.2)$ & $5.3(1.0)$ & $1.1(0.2)$ & $1.7(0.4)$ \\
\hline H. platessoides & 1 & 3 & $28.3(0.8)$ & $14.4(1.5)$ & $8.3(1.8)$ & $4(1.2)$ & $4.4(0.5)$ & $3.1(1.1)$ \\
\hline L. digitata & 6 & 3 & $0.4(0.4)$ & $2.3(1.2)$ & $20.1(14.7)$ & $5.8(2.4)$ & $1.6(0.5)$ & $2.0(1.6)$ \\
\hline M. aeglefinus & 1 & 3 & $30.5(1.4)$ & $19.6(0.3)$ & $6.6(1.0)$ & $1.6(0.2)$ & $3.9(0.6)$ & $2.4(0.2)$ \\
\hline P. borealis (large) & 6 & 3 & $17.1(1.9)$ & $21.4(2.1)$ & $10.2(0.4)$ & $5.5(1.2)$ & $3.0(0.3)$ & $2.4(0.2)$ \\
\hline P. borealis (small) & 6 & 3 & $20.2(0.0)$ & $19.6(0.5)$ & $7.8(0.7)$ & $4.1(0.5)$ & $3.2(0.1)$ & $1.7(0.4)$ \\
\hline P. elegans & 5 & 3 & $21.4(0.6)$ & $13.4(0.2)$ & $8.2(0.5)$ & $6.3(0.5)$ & $1.6(0.2)$ & $0.4(0.0)$ \\
\hline R. confervoides & 6 & 1 & 3.5 & 21.2 & 3.9 & 18 & 1.1 & 2.1 \\
\hline S. septemcarinata & 3 & 3 & $10.5(2.8)$ & $20.1(2.0)$ & $7.1(1.3)$ & $7.4(3.2)$ & $4.4(0.6)$ & $3.5(0.5)$ \\
\hline \multirow[t]{2}{*}{ Bottom water POM } & 4 & 3 & $1(0.9)$ & $1.5(1.4)$ & $15.6(7.3)$ & $5.0(1.3)$ & $23.2(3.0)$ & $0.0(0.0)$ \\
\hline & \multicolumn{8}{|c|}{ January } \\
\hline Taxon & Map \# & $\mathbf{n}$ & $22: 6 \omega-3$ & $20: 5 \omega-3$ & $18: 1 \omega-9$ & $16: 1 \omega-7$ & 18:0 & $20: 4 \omega-6$ \\
\hline A. phyllonyx & 10 & 3 & $9.5(0.8)$ & $13.9(2.1)$ & $8.8(0.3)$ & $5.3(0.3)$ & $1.9(0.1)$ & $13.9(0.8)$ \\
\hline H. fulvocinctus & $14,21,22$ & 1 & 9.6 & 12.6 & 20.4 & 4.9 & 0.8 & 0.8 \\
\hline H. platessoides & 13 & 3 & $13.0(3.1)$ & $12.9(2.4)$ & $8.3(1.9)$ & $7.4(4.5)$ & $3.4(0.8)$ & $2.0(1.1)$ \\
\hline M.aeglefinus & 13 & 3 & $32.6(0.8)$ & $17(2.3)$ & $7.5(2.1)$ & $1.6(0.4)$ & $4.4(0.4)$ & $2.4(0.4)$ \\
\hline P. borealis (large) & 10 & 3 & $17.9(1.7)$ & $22.3(0.8)$ & $12.9(2.0)$ & $4.9(0.5)$ & $2.2(0.1)$ & $1.7(0.2)$ \\
\hline P. borealis (small) & 10 & 3 & $18.8(1.3)$ & $19.4(0.6)$ & $10.5(1.0)$ & $5.1(0.7)$ & $2.1(0.3)$ & $2.0(0.4)$ \\
\hline P. elegans & 10 & 3 & $18.5(0.8)$ & $11.9(0.4)$ & $6.7(0.3)$ & $8.4(0.6)$ & $1.2(0.3)$ & $0.4(0.1)$ \\
\hline S. septemcarinata & 14 & 3 & $16.3(6.1)$ & $24.8(2.0)$ & $6.8(1.6)$ & $4.1(1.7)$ & $4.2(0.5)$ & $4.1(0.4)$ \\
\hline Bottom water POM & 12 & 3 & $1.1(0.5)$ & $1.1(0.7)$ & $16.9(12.8)$ & $4.7(1.6)$ & $16.8(2.8)$ & $0.3(0.2)$ \\
\hline
\end{tabular}

Editorial responsibility: Stephen Wing, Dunedin, New Zealand
Submitted: March 1, 2018; Accepted: July 26, 2018

Proofs received from author(s): September 8, 2018 